\title{
Islet organoid as a promising model for diabetes
}

\author{
Xiaofei Zhang ${ }^{1,2}$, Zhuo Ma ${ }^{1,3}$, Eli Song ${ }^{1,3 \bowtie}$ (D), Tao $\mathrm{Xu}^{1,3,4 \bowtie}$ (D) \\ ${ }^{1}$ National Laboratory of Biomacromolecules, CAS Center for Excellence in Biomacromolecules, Institute of Biophysics, \\ Chinese Academy of Sciences, Beijing 100101, China \\ ${ }^{2}$ Key Laboratory of Molecular Biophysics of the Ministry of Education, College of Life Science and Technology, Huazhong \\ University of Science and Technology, Wuhan 430074, China \\ ${ }^{3}$ College of Life Sciences, University of Chinese Academy of Sciences, Beijing 100049, China \\ ${ }^{4}$ Guangzhou Regenerative Medicine and Health Guangdong Laboratory (Bioland Laboratory), Guangzhou 510005, China \\ $\bowtie$ Correspondence: songali@ibp.ac.cn (E. Song), xutao@ibp.ac.cn (T. Xu)
}

Received July 16, 2020 Accepted January 22, 2021

\begin{abstract}
Studies on diabetes have long been hampered by a lack of authentic disease models that, ideally, should be unlimited and able to recapitulate the abnormalities involved in the development, structure, and function of human pancreatic islets under pathological conditions. Stem cell-based islet organoids faithfully recapitulate islet development in vitro and provide large amounts of three-dimensional functional islet biomimetic materials with a morphological structure and cellular composition similar to those of native islets. Thus, islet organoids hold great promise for modeling islet development and function, deciphering the mechanisms underlying the onset of diabetes, providing an in vitro human organ model for infection of viruses such as SARS-CoV-2, and contributing to drug screening and autologous islet transplantation. However, the currently established islet organoids are generally immature compared with native islets, and further efforts should be made to improve the heterogeneity and functionality of islet organoids, making it an authentic and informative disease model for diabetes. Here, we review the advances and challenges in the generation of islet organoids, focusing on human pluripotent stem cell-derived islet organoids, and the potential applications of islet organoids as disease models and regenerative therapies for diabetes.
\end{abstract}

KEYWORDS islet organoid, diabetes, pluripotent/adult stem cell, pancreatic $\beta$ cell, disease model

Xiaofei Zhang and Zhuo Ma have contributed equally to this work.

\section{INTRODUCTION}

Diabetes mellitus, characterized by hyperglycemia, is a prevalent metabolic disease affecting more than 400 million people worldwide that can lead to various severe complications and premature death (Saeedi et al., 2019). Type 1 diabetes (T1D) is an autoimmune disease that results in the dysfunction of $\beta$ cells. Type 2 diabetes (T2D), the most common form in adults, is characterized by peripheral insulin resistance and relatively insufficient insulin secretion (Ashcroft and Rorsman, 2012). In addition, an increasing number of rare monogenic diabetes, including maturity-onset diabetes of the young (MODY) and neonatal diabetes (ND), which result from mutations in a single gene involved in pancreatic $\beta$ cell development or function, have been identified (Ashcroft and Rorsman, 2012; Bishay and Greenfield, 2016). Unfortunately, both the pathogenesis of diabetes and effective therapeutic regimens remain largely unclear.

The pancreatic islet is an essential endocrine organ that secretes hormones for blood glucose homeostasis. It comprises five endocrine cell types, namely, $\sim 60 \%$ insulin (INS)producing $\beta$ cells, $\sim 30 \%$ glucagon (GCG)-producing a cells, $\sim 10 \%$ somatostatin (SST)-producing $\delta$ cells, a low percentage of pancreatic polypeptide (PPY)-producing Y/PP cells, very few ghrelin (GHRL)-producing $\varepsilon$ cells (Brissova et al., 2005; Cabrera et al., 2006), and an abundance of supporting cells (e.g., endothelial cells, macrophages, and nerve cells) (Mattsson, 2005; Aamodt and Powers, 2017). During development, islets originate from separate dorsal and ventral pancreatic buds, which then merge and expand through cell proliferation (Pictet et al., 1972; Shih et al., 2013). Simultaneously, $\mathrm{NGN3}^{+}$cells delaminate from the 
developing pancreatic ducts to initiate islet development (Rukstalis and Habener, 2007; Gouzi et al., 2011; Shih et al., 2013), which is a delicate process that is precisely regulated by a series of transcription factors, including PDX1, NKX2.2, NKX6.1, and PAX6 (Oliver-Krasinski and Stoffers, 2008; Jennings et al., 2015; Youn et al., 2016). Unfortunately, the morphogenesis, signaling pathways and key factors involved in islet development remain largely unknown, resulting from interspecies difference, scarcity of human donors, and ethical considerations concerning human embryo research.

Organoid is a cutting-edge technology providing new models for developmental biology and disease research (Lancaster and Knoblich, 2014; Fatehullah et al., 2016; Dutta et al., 2017; Schutgens and Clevers, 2020). Organoids are three-dimensional (3D) cultures derived from stem cells, either pluripotent stem cells (PSCs) or organ-restricted adult stem cells (ASCs) and can mimic specific organ functions (Lancaster and Knoblich, 2014). Compared with animal models, organoids can be of human origin and thus can obviate the need to extrapolate discoveries from model animals to humans; compared with organ models derived directly from humans, organoids are more readily available and can be personalized. In clinical applications, organoids can serve as personalized high-throughput drug screening platforms with which to evaluate potential therapeutic efficacies, and as new sources for organ transplants due to their functionality (Fatehullah et al., 2016; Dutta et al., 2017; Schutgens and Clevers, 2020). However, current organoid systems have many problems, including limited cell compositions, insufficient maturity, incomplete function, and poor vascularization.

Because islets are closely involved in the occurrence and development of diabetes, islet organoids have attracted increasing attention. Pancreatic $\beta$ cells are considered the most essential components of islets; thus, previous studies paid more attention to the generation of $\beta$ cells from stem cells, termed stem cell-derived $\beta$ (sc- $\beta$ ) cells (Pagliuca et al., 2014). Recently, rapid increasing progress has been made in sc- $\beta$ cell generation and islet organoid model development. Here, we review the advances and challenges in establishing islet organoids and discuss their potential application.

\section{STATE-OF-THE-ART STRATEGIES TO ESTABLISH ISLET ORGANOIDS}

The mystery of human pancreas development has been partially uncovered. Some key signaling pathways, including the BMP, NOTCH, and canonical and noncanonical WNT pathways, and a few regulatory genes, including NKX2.2, NEUROD1, and ISL1, have been characterized (reviewed in (Jennings et al., 2015; Nair and Hebrok, 2015; Petersen et al., 2018; Yu and Xu, 2020)). Based on current knowledge about the mechanism of human islet development, a series of studies have developed various recipes combining panels of growth factors and small molecules to sequentially manipulate the signaling pathways to guide the commitment of hPSCs to a $\beta$ cell fate (D'Amour et al., 2006; Kroon et al., 2008; Rezania et al., 2012). However, in these previous studies, the immaturity of sc- $\beta$ cells, as demonstrated by the poor glucose responsiveness, polyhormonal signatures, and preferential commitment of the polyhormonal cells to $\alpha$ instead of $\beta$ cells, has been reported (Kelly et al., 2011; Basford et al., 2012; Rezania et al., 2013; Bruin et al., 2014; Hrvatin et al., 2014). Currently, functional maturation relies mostly on in vivo transplantation (Rezania et al., 2013, 2014; Augsornworawat et al., 2020), but the underlying mechanisms remain unknown. Considerable efforts have been made to derive functional islet organoids in vitro.

\section{Optimization of recipes to obtain functional $\beta$-like cells}

Recently, several groups have reported refined recipes to generate sc- $\beta$ cells or accomplish islet regeneration in vitro. The design of these recipes relied mainly on current knowledge of pancreas development to in vitro mimic the natural microenvironment corresponding to specific developmental stages; therefore, most protocols share certain induction pathways, although disparities exist (summarized in Fig. 1A). Pagliuca et al. systematically tested $>150$ combinations of $>70$ compounds to formulate a 6-step protocol, which generated $\sim 33 \%$ sc- $\beta$ cells resembling primary $\beta$ cells at the molecular, ultrastructural, and functional levels (Pagliuca et al., 2014). These sc- $\beta$ cells expressed certain canonical $\beta$ cell marker genes, including PDX1 and ZNT8, and possessed both developing and mature crystallized insulin granules, where normal insulin processing occurs (Pagliuca et al., 2014). Functionally, these cells repeatedly increased the intracellular $\mathrm{Ca}^{2+}$ and secreted insulin upon sequential glucose changes in vitro and rapidly restored euglycemia in a diabetic mouse model after transplantation, closely resembling the native islets (Pagliuca et al., 2014). As determined by multiomics analysis, three other major cell types in addition to sc- $\beta$ cells existed among the final induction products, namely, $\alpha$-like cells, an unexpected population of enterochromaffin cells, and SOX $9^{+}$pancreatic progenitors, which tend to generate exocrine cells upon further induction (Veres et al., 2019). Multiomics analysis further delineated the process of in vitro islet specification and identified two sequential lineage bifurcations, which lay at the initiation points of endocrine cell and $\beta$ cell formation (Sharon et al., 2019; Veres et al., 2019; AlvarezDominguez et al., 2020). Each of the two bifurcations led to a dramatic decrease in induction efficiency and an increase in induction product heterogeneity (Sharon et al., 2019; Veres et al., 2019).

The immaturity of the sc- $\beta$ cells was attributed partially to the premature induction of early precursors due to the premature expression of NGN3 in the early stages (Johansson et al., 2007). Rezania et al. introduced vitamin C during induction of the pancreatic endoderm to suppress precocious NGN3 expression and the downstream targets, NEUROD1 and NKX2.2 (Rezania et al., 2014). Vitamin C also 
A

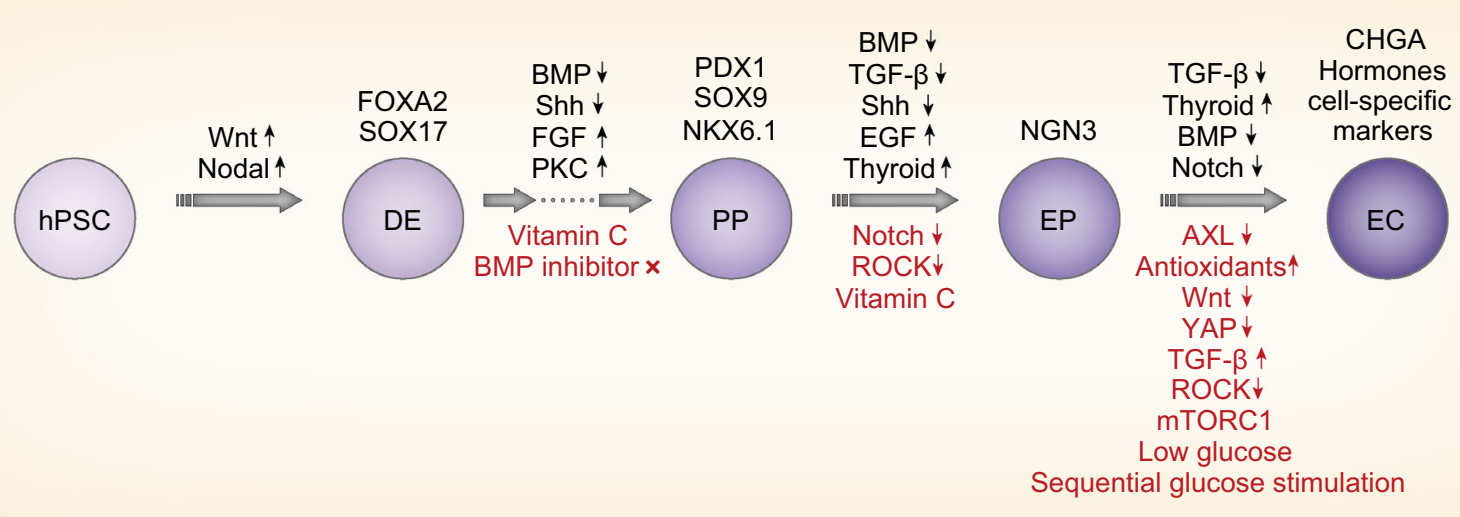

B

Suspension-based 3D culture Suspension Air-liquid interface Spinner flasks Organ-on-a-chip
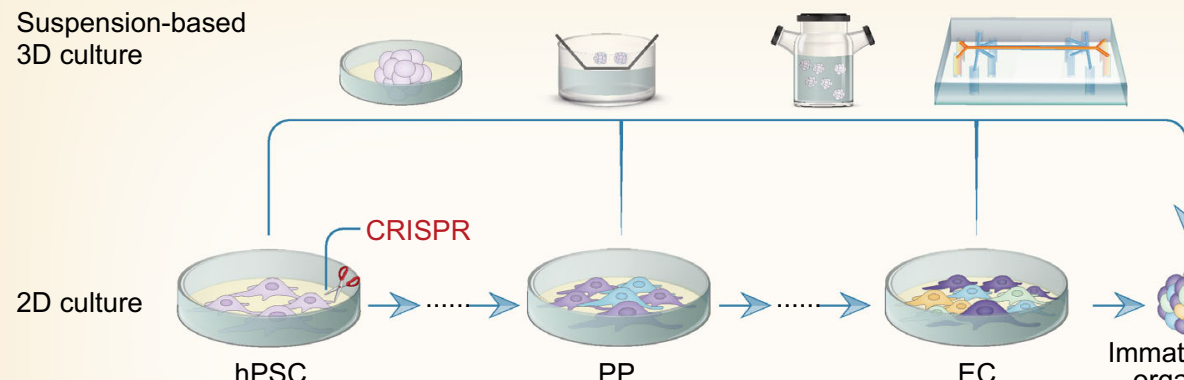

hPSC

PP

EC

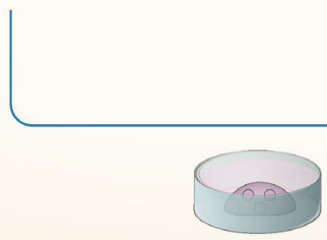

Embedding in ECM

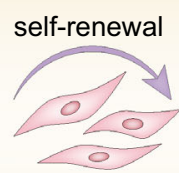

Islet progenitors or stem cells
Co-culture with endothelial cells or other cells

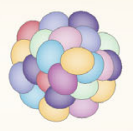

Islet organoids

Figure 1. State-of-the-art strategies to establish islet organoids. (A) Signaling pathways typically manipulated to induce differentiation of sc- $\beta$ cells. Generally, hPSCs are sequentially differentiated to definitive endoderm (DE), pancreatic progenitors (PP), endocrine precursors (EP) and endocrine cells (EC), as shown by markers of each stage. The pathways in black are commonly manipulated in the most widely used protocols (Pagliuca et al., 2014; Rezania et al., 2014; Russ et al., 2015; Nair et al., 2019), and the pathways in red are specifically reported to facilitate endocrine specification (Ghazizadeh et al., 2017; Rosado-Olivieri et al., 2019; Sharon et al., 2019; Velazco-Cruz et al., 2019; Helman et al., 2020; Hogrebe et al., 2020). (B) Strategies currently leveraged to establish 3D islet organoids. Strategies in black are used to establish 3D islet organoids, relying on either suspension or scaffold culture. 3D culture starting from different time points has been reported. Strategies in red are applied to improve the maturity of 3D islet organoids, focusing mainly on improving vascularization and recovering metabolic defects of the immature islet organoids. (C) Strategies for ASC-derived islet organoids. Islet progenitors can be isolated from the adult pancreas and then form islet organoids with endothelial cells or other cells. 
regulates extracellular matrix (ECM) production and increases cell confluency (Choi et al., 2008). With addition of vitamin C, a population containing approximately $50 \%$ insulin ${ }^{+} / \mathrm{NKX} 6.1^{+}$and $\mathrm{KCl}$-responding cells appeared after $\beta$ cell induction; however, these cells failed to respond to high glucose concentrations, indicating their immaturity and the requirement for additional maturation steps (Rezania et al., 2014). Further screening of compounds capable of inducing MAFA, a marker of mature $\beta$ cells, formulated a 7-step protocol. With this updated protocol, the majority of endocrine cells in the final products were $\beta$-like cells, $\sim 5 \%-10 \%$ of which rapidly increased the cytosolic $\mathrm{Ca}^{2+}$ concentration upon glucose challenge. Although significant glucose stimulated insulin secretion (GSIS) was not observed, the $\beta$-like cells slowly accumulated insulin upon glucose responsiveness (Rezania et al., 2014).

The role of vitamin C in suppressing NGN3 expression is somewhat cell-specific. Russ et al. showed that NGN3 transcripts were not reduced in other cell lines upon vitamin C treatment (Russ et al., 2015). They omitted BMP inhibitor treatment during the induction of pancreatic progenitors to prevent premature endocrine commitment, instead treating progenitors with the BMP inhibitor noggin to induce endocrine precursors, allowing spontaneous differentiation into $\sim 20 \%$ monohormonal glucose-responding $\beta$-like cells in basal medium (Russ et al., 2015). However, omission of noggin during the early pancreatic progenitor step was recently found to induce the expression of CDX2, a marker of intestinal development, at the expense of losing NKX6.1 expression and the ability for further differentiation into endocrine cells (Wesolowska-Andersen et al., 2020). However, different cell lines were employed in these studies; therefore, the action of noggin could be a cell-specific effect, as also observed with other factors, including TPB or PdBU for PKC activation, and dorsomorphin or noggin for BMP inhibition (Kunisada et al., 2012; Rezania et al., 2012; Pagliuca et al., 2014; Nostro et al., 2015). Most recently, Hogrebe et al. developed a two-dimensional (2D) protocol using latrunculin $A$ to depolymerize the cytoskeleton during endocrine induction and strongly improve the in vitro and in vivo function of sc- $\beta$ cells (Hogrebe et al., 2020).

In addition to adjusting the combinations of growth factors and small molecules, decreasing the exposure time to the progenitor-inducing cocktail yielded fewer polyhormonal cells and more NKX6.1 $1^{+}$multipotent progenitors (Nostro et al., 2015). Intriguingly, increased induction efficiency was observed by halving the cell density after the endodermal stage and extending the progenitor-inducing time (Memon et al., 2018). These results indicate that the efficiency of sc- $\beta$ cell differentiation from hPSCs is mysteriously correlated with cell density, induction recipe, and cell lines.

\section{Strategies to establish 3D islet organoids}

In addition to elaborate chemical recipes, the role of 3D microenvironments for in vitro islet development has been extensively investigated. Islets are densely packed 3D architectures with specific cell distribution patterns in which cell-cell interactions have significant roles in regulating cell fate specification and islet function (Roscioni et al., 2016). These roles were ignored in early attempts to establish $\beta$-like cells in vitro, which partially accounted for the immaturity of the derived $\beta$-like cells due to diminished growth factor gradients. Spontaneous clustering was observed when hPSC-derived endodermal cells were replaced with a quartered density (Memon et al., 2018) or when monolayer-cultured hPSCs were induced toward the posterior foregut on Matrigel-coated dishes (Broda et al., 2019). The former generated clusters containing unusual PDX1-/NKX6.1 progenitors, and the latter have not been used for islet organoids.

\section{Suspension-based 3D culture}

The self-organization capacity of hPSCs has been widely employed to aggregate dissociated hPSCs into 3D embryonic bodies (EBs) with variable diameters dependent on the culture system (Fig. 1B). Pagliuca et al. utilized a stir plate to apply a constant rotation to hPSCs cultured in spinner flasks to generate $\sim 100-200-\mu \mathrm{m}$ cell clusters. Morphologically and functionally, these clusters resembled native human islets; however, few non- $\beta$ endocrine cells were detected compared with those in human islets (Pagliuca et al., 2014). Dissociation and reclustering of islet organoids in the final stage have been reported to further improve functionality (VelazcoCruz et al., 2019).

Microfluidic devices offer a more sophisticated suspension-based strategy. Microfluidic perfusable systems continuously deliver induction signals or nutrients while removing metabolic wastes. Furthermore, perfusion enables the application of mechanical cues, such as physiologically relevant flow-induced shear stress. Compared with the products obtained under static culture conditions, perfusable system-generated islet organoids have increased cell viability, elevated expression of mature endocrine cell markers, and significantly improved islet function (Tao et al., 2019).

Although 3D architecture plays a pivotal role in maturing islet organoids, the appropriate stage at which to apply 3D culture remains debatable. Compared with 3D suspension culture, 2D planar culture prevented pancreatic progenitors from prematurely expressing NGN3 but inhibited their further differentiation toward the endocrine lineage, indicating the significance of timing in 3D culture initiation (Hogrebe et al., 2020). Initiation of 3D culture at different stages has been reported. Inspired by the aggregated distribution of $\mathrm{PDX} 1^{+} /$ NKX6. $1^{+}$pancreatic progenitors in monolayer culture (Toyoda et al., 2015; Mamidi et al., 2018), starting suspension culture from progenitors increased the proportion of $\mathrm{PDX} 1^{+} /$ NKX6. $1^{+}$cells and the expression levels of PDX1 (Toyoda et al., 2015). The transfer of planar pancreatic endodermal cells to an air-liquid interface allowed apical-basal polarity and generated $\sim 1-2-\mathrm{mm}$ clusters with enhanced NGN3, 
INS, GCG and SST expression (Rezania et al., 2014). Direct evidence showing the impact of the 3D structure on islet organoid maturation was provided by comparing $2 \mathrm{D}$ sc- $\beta$ cells and their clustered counterparts. A static suspension culture of dissociated sc- $\beta$ cells generated $\sim 50-150-\mu \mathrm{m}$ endocrine cell clusters (ECCs) with significantly augmented coexpression of PDX1/NKX6.1 and PDX1/GLUT1; reduced expression of MAFB, a marker of endocrine progenitors; and improved functional maturation (Kim et al., 2016). The ECCs contained all endocrine cell types except a cells; however, cell heterogeneity has not been promoted by clustering, as shown by decrease of PPY and GCG expression (Kim et al., 2016). Nair et al. further examined the metabolic mechanisms underlying clustering-facilitated $\beta$ cell maturation and revealed the role of clustering-promoted mitochondrial oxidative respiration in the metabolic maturation of $\beta$ cells (Nair et al., 2019).

\section{Scaffold-based 3D culture}

Instead of relying on self-organization to establish 3D structures, other strategies incorporated ECM components as scaffolds to promote $3 \mathrm{D}$ structure formation and cellmatrix interactions (Fig. 1B). Dissociated mouse embryonic pancreatic progenitors can survive in $2 \mathrm{D}$ culture, but only in Matrigel organoids can be formed, highlighting the role of cell-matrix interactions in cell fate specification (Greggio et al., 2013). 3D islet organoids built within a scaffold combining collagen and Matrigel (C-M scaffold) yielded $\alpha, \beta, \gamma$ and PP cells (Wang et al., 2017). The $\beta$-like cells expressed elevated levels of INS, GLUT2 and MAFA and harbored 12-fold more insulin granules than their $2 \mathrm{D}$ cultured counterparts. In addition to facilitating late-stage maturation of endocrine cells, the C-M scaffold also provides a favorable microenvironment for endocrine commitment in the early developmental processes, as manifested by the reduced expression of HNF6 (restricted in exocrine cells in the native pancreas) in 3D pancreatic progenitors compared with planar counterparts (Wang et al., 2017). Candiello et al. devised a novel hydrogel-based platform called "Amikagel" by polymerizing amikacin hydrate and polyethyleneglycol diglycidyl ether (PEGDE), which facilitated the self-aggregation of hESC-derived pancreatic progenitor cells and their coaggregation with supporting endothelial cells (Candiello et al., 2018). Amikagel-produced 3D cell aggregates had increased populations of cells coexpressing NKX6.1/PDX1, increased expression of insulin/C-peptide, and enhanced glucose responsiveness (Candiello et al., 2018). Islet organoids cultured in a microporous scaffold showed improved control over islet organoid size and cell-cell interactions. These $\sim 250-425-\mu \mathrm{m}$ islet organoids had more mature marker expression and performed better in GSIS than their counterparts in suspension culture (Youngblood et al., 2019).

Using a decellularized pancreas as a scaffold is another elaborate and effective strategy to provide an intact biomimetic ECM microenvironment for supporting the differentiation and maturation of sc- $\beta$ cells. This strategy includes the perfusion of decellularization reagents to completely remove cells residing in the pancreas followed by perfusion of a cell suspension to recellularize the scaffolds. The scaffold retains biochemical signals with ECM proteins and can mimic biophysical signals, such as shear stress, during recellularization. Mouse iPSC-derived $\beta$-like cells have been perfused into decellularized scaffolds and matured into functional $\beta$-like cells (Wan et al., 2017). Decellularized ECM hydrogels offer another more flexible microenvironment, in which the ECM composition can be manipulated and the embedding of cells is more convenient than recellularization. Native islets cultured in decellularized pancreatic ECM exhibited improved glucose responsiveness and enhanced viability of both islets and islet-resident endothelial cells (Jiang et al., 2019).

Proteomic analysis of decellularized rat pancreas revealed that collagen $\mathrm{V}$ was a crucial component in the islet niche (Bi et al., 2020). Suspension cultures of hPSCs in collagen V-augmented Matrigel-coated dishes generated more mature islet cells (Bi et al., 2020). Notably, in addition to biochemical signals guiding cell fate determination, the ECM components surrounding the developing cells are also in continuous flux to regulate cell differentiation to different stages. Enrichment of certain ECM components, such as laminin, promoted bipotent pancreatic progenitors to commit to endocrine cell specification, while exposure to other ECM components led to duct cell differentiation (Mamidi et al., 2018), implying that stage-specific scaffolds may facilitate endocrine differentiation in vitro and improve the induction efficiency.

Innovative strategies facilitating functional maturation of islet organoids

In addition to optimization of the induction protocol and establishment of 3D structures, instructive strategies derived from the current understanding of the islet developmental process have facilitated the maturation of sc- $\beta$ cells.

\section{Vascularized islet organoids}

In vivo maturation of islet organoids or hPSC-derived pancreatic progenitors typically generates islet organoids that are morphologically and functionally similar to native islets (Rezania et al., 2013, 2014; Augsornworawat et al., 2020). One of the key disparities between the features of islet organoids derived from in vitro environments and those derived from in vivo environments is their vascular networks, which are abundant in native islets and transplanted islet organoids but scarce in in vitro-derived products (Ranjan et al., 2009; Eberhard et al., 2010; Sneddon et al., 2018). Islets are considered one of the most highly vascularized organs due to their endocrine features. Therefore, vascularization is vital for islet development and endocrine function, and lack of vascular networks reduces not only the 
fidelity of islet organoids but also their viability during in vitro culture because of the insufficient nutrient and oxygen supply to deeply buried cells. Many strategies have attempted in vitro vascularization by coculturing endothelial cells with endocrine cells. Taniguchi's group reported that coculturing of cell lines, native tissue fragments, and iPSC spheroids with human umbilical vein endothelial cells (HUVECs) and mesenchymal stem cells (MSCs) in Matrigel enabled the formation of vascularized islet organoids (Fig. 1B) (Takahashi et al., 2018a; Takahashi et al., 2018b). Gene expression patterns of the vascularized islet organoids reflected native islets better than those of non-vascularized islets (Takahashi et al., 2018a). Furthermore, a vascular-inductive bed was established by functionalizing the bioactive polyethylene glycol (PEG) hydrogel with vascular endothelial growth factor A (VEGFA), which is widely believed to be secreted by early $\beta$ cells during embryonic development to recruit endothelial cells and promote the formation and expansion of the vasculature (Phelps et al., 2013). This protocol facilitated intraislet vasculature formation and significantly improved the functional performance of islets embedded in this bed and delivered to the small bowel mesentery in a diabetic mouse model (Phelps et al., 2013).

\section{Other strategies}

Core circadian clock activators have been predicted to facilitate maturation of the epigenomic dynamics of islet organoids (Alvarez-Dominguez et al., 2020). Daily circadian rhythms in islet organoids tuned, but did not elicit, glucose responsiveness by increasing the glucose threshold of GSIS (Alvarez-Dominguez et al., 2020). Defective GSIS but normal $\mathrm{KCl}$ responsiveness of $\beta$-like cells have been demonstrated in various studies. A possible reason for this impaired glucose sensing and GSIS is reduced anaplerotic cycling stemming from reduced GAPDH and PGK activity (Davis et al., 2020). The use of cell-permeable intermediate metabolites downstream of these two enzymes successfully improved islet function (Davis et al., 2020).

Gene manipulation has also been considered for the maturation of islet organoids. Inducible knockout of LIN28B after definitive endoderm formation significantly improved GSIS of the derived islet organoids, but the expression of mature islet markers was not significantly upregulated (Zhou et al., 2020). Overexpression of ERRy, an important regulator of mitochondrial oxidative ATP biosynthesis, increased the glucose responsiveness of $\beta$-like cells in vitro and in vivo (Yoshihara et al., 2016).

Noncanonical WNT signaling was reported to participate in pancreas specification and islet maturation (RodriguezSeguel et al., 2013; Yoshihara et al., 2020). Correspondingly, treatment of immature islet organoids with WNT4, an activator of noncanonical WNT signaling, significantly increased mitochondrial content and oxidative metabolism and improved GSIS in vitro, without affecting cell fate determination (Yoshihara et al., 2020). Enrichment of the CD177 cell subpopulations from induced definitive endoderm, in which WNT/PCP signaling was specifically activated, generated a higher percentage of MAFA ${ }^{+}$mature sc- $\beta$ cells with elevated glucose responsiveness (Mahaddalkar et al., 2020).

\section{Islet organoids derived from ASCs and other sources}

ASCs residing in adult tissues have the capacity for selfrenewal and differentiation under certain conditions, and they are considered another potential source for organoids (Clevers, 2016). In contrast to PSC-derived organoids, ASCderived organoids have the identity of a given organ (Fig. 1C) (Habener, 2004) and are able to avoid tumorigenicity in potential clinical applications. There is a longstanding debate regarding whether the adult pancreas contains stem or progenitor cells. Several particular cell groups have been proposed as pancreatic progenitor or progenitorlike cells, which have the ability to differentiate into insulinsecreting cells in vitro, including Nestin-positive cells isolated from mouse pancreas (Wei et al., 2012), cells with high aldehyde dehydrogenase enzyme activity sorted from human fetal and adult pancreas (Loomans et al., 2018; Oakie et al., 2018), and P2RY1- and ALK3-positive cells sorted from human pancreatic ducts (Qadir et al., 2018; Qadir et al., 2020). Recently, a new population of Procr ${ }^{+}$ endocrine progenitors was identified from adult mouse islets (Wang et al., 2020). Procr ${ }^{+}$progenitors can generate functional endocrine cells in vitro and in vivo, and islet organoids derived from Procr $^{+}$cells are capable of reversing hyperglycemia in a mouse model of streptozotocin-induced T1D (Wang et al., 2020). Additionally, non- $\beta$ endocrine cells, pancreatic exocrine cells, and even nonpancreatic cells such as intestinal enteroendocrine cells have been demonstrated to transdifferentiate into insulin-secreting cells by reprogramming in some cases (Thorel et al., 2010; Chen et al., 2014; Lemper et al., 2015). However, genetic lineage-tracing studies indicated that the exocrine compartment was unlikely to contribute to the formation of endocrine cells in vivo (Aguayo-Mazzucato and Bonner-Weir, 2018; DominguezBendala et al., 2019). The current dominant view is that the replenishment of adult pancreatic $\beta$ cells relies principally on their self-duplication instead of potential pancreatic stem cell differentiation (Dor et al., 2004).

\section{APPLICATIONS OF ISLET ORGANOIDS}

As the developmental and functional properties of islet organoids have become more representative of physiological human islets, islet organoids can function as surrogates for inaccessible human islets, especially those from diabetic individuals. The combination of gene editing technologies, 


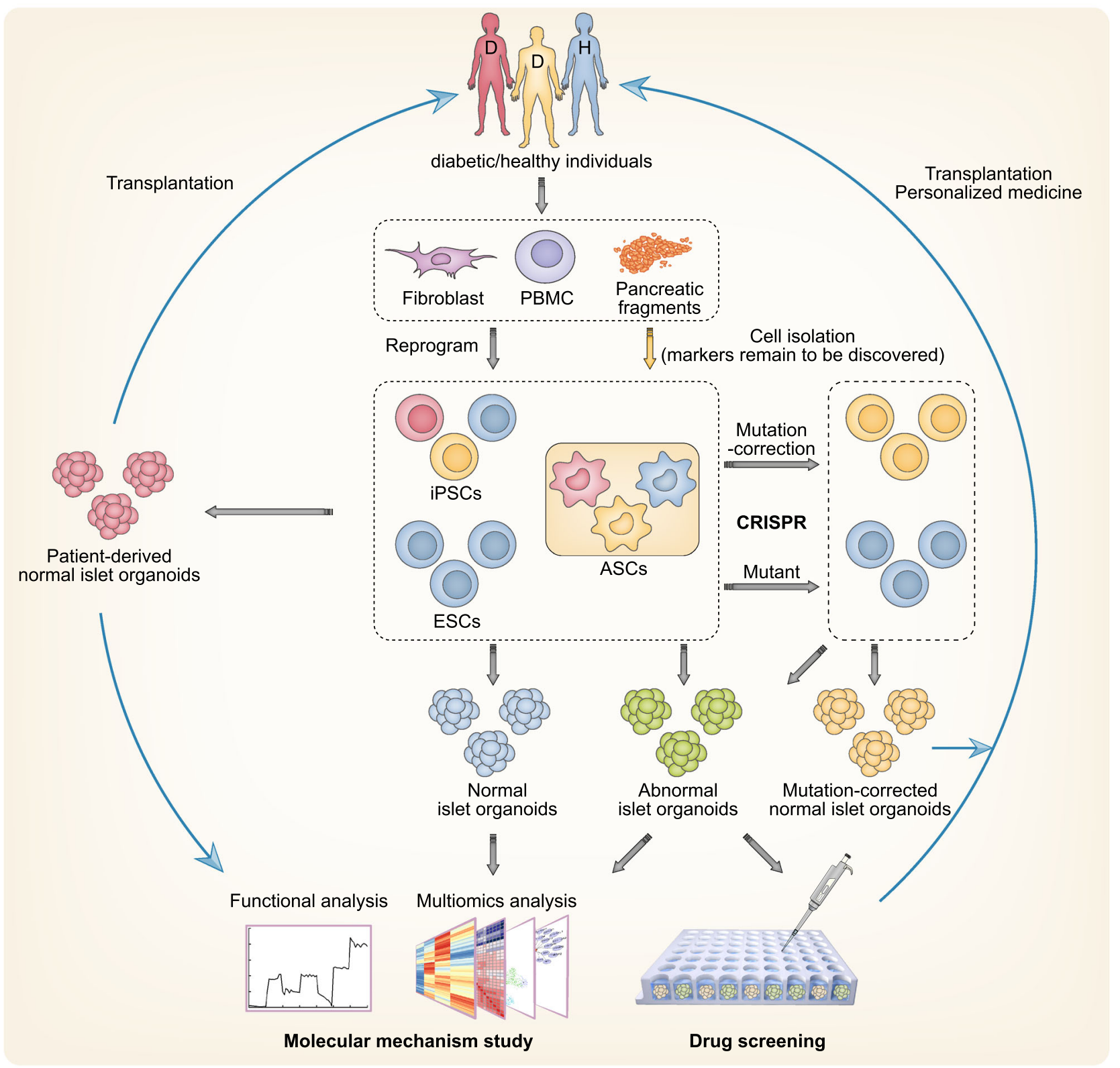

Figure 2. Promising applications of islet organoids in disease modeling and personalized medicine. Personalized islet organoids can be derived from either iPSCs reprogrammed from fibroblasts/peripheral blood mononuclear cells (PBMCs) or ASCs sorted from pancreatic fragments. Islet organoids derived from hESCs or iPSCs reprogrammed from healthy individuals are able to serve as a novel model system for human islet development and function research. Patient-derived iPSCs/ASCs can be used to generate functional islet organoids with or without mutation correction (Millman et al., 2016; Manzar et al., 2017; Saarimaki-Vire et al., 2017; Balboa et al., 2018; Ma et al., 2018; Maxwell et al., 2020), providing unlimited sources of islets for autologous transplantation. The abnormal islet organoids derived from patients or gene-edited hESCs faithfully recapitulate developmental and functional defects under pathological conditions, offering novel valuable platforms for the study of pathological mechanisms and personalized drug screening.

such as CRISPR/Cas9 and refined iPSC technology, allows the manipulation of islet organoids to investigate the developmental, functional, and pathological mechanisms of normal and diabetic human islets and to develop personalized and informative drug screening platforms (Fig. 2).

\section{Models for studying islet development}

Although the mechanisms governing islet development are largely conserved between human and murine models, human-specific developmental events and structural or 
functional characteristics arise remarkable attention (Nair and Hebrok, 2015). Islet organoids derived from hPSCs are a promising system for investigating pivotal niche signals and biochemical or biophysical mechanisms governing islet development and developmental defects that result in congenital diabetes. In turn, this information can be further used to improve the design of differentiation strategies to enhance the maturation of islet organoids. Using sc- $\beta$ cells, Sharon et al. found that WNT inhibition was a major regulatory mechanism in endocrine differentiation, capable of adjusting the induction output of $\beta$-like cells (Sharon et al., 2019). Adjusting the balance between proliferation and differentiation of pancreatic progenitors could expand the progenitor population to generate increased numbers of endocrine cells and force the differentiation of the pancreatic progenitors to eliminate undesired progenitors. However, effective strategies to manipulate this balance have not yet been developed. A possible solution is inhibition of YAP to manipulate the Hippo signaling pathway, whose activation facilitates pancreatic progenitor proliferation and whose inhibition favors endocrine specification (Rosado-Olivieri et al., 2019). Overexpression of YAP in $\beta$-like cells of derived islet organoids revealed a subpopulation of $\beta$ cells with activated LIF pathways and increased proliferative capacity (Rosado-Olivieri et al., 2020), indicating the ability of these cells to reflect subtle characteristics of human islets.

Combined with gene editing technologies such as CRISPR/Cas9, organoids have the capacity to accomplish the incomplete gene regulatory network of islet development and pathogenesis. CRISPR screening in sc- $\beta$ cells identified that the vitamin $D$ receptor (VDR) is required for $\beta$ cell differentiation and maintenance in vitro, and subsequent studies revealed an unrecognized role of VDR in $\beta$ cell survival under inflammatory stress (Wei et al., 2018). Combining a novel gene editing platform termed iCRISPR and hPSC-directed differentiation, Zhu et al. confirmed the roles of conserved transcription factors in mice and humans, revealed the novel regulator RFX6 in the specification of pancreatic progenitors, and reported an intriguing haploinsufficiency requirement of PDX1 in endocrine differentiation (Zhu et al., 2016). Moreover, NGN3 ${ }^{-1-}$ hPSC derivatives showed negligible functional endocrine specification in several independent studies (McGrath et al., 2015; Zhu et al., 2016), and some patients carrying NGN3 mutations retained at least partial endocrine function. Using $N G N 3^{-/-} \mathrm{hPSC}$ derivatives, Zhang et al. found that NGN3 mutations affected protein instability and DNA binding capacity during pancreas development (Zhang et al., 2019). Another transcription factor, MAFB, is expressed in adult human $\beta$-cells but absent from the murine counterparts. Using CRISPR/Cas 9 gene editing coupled with endocrine cell differentiation strategies, Russell et al. generated MAFB knockout hPSCs and revealed that MAFB is essential for human $\beta$-cell identity during endocrine cell development (Russell et al., 2020). Applying state-of-the-art strategies to establish 3D islet organoids may further systematically elucidate the developmental and functional mechanisms involving $\beta$ cells and their regulatory interactions with non- $\beta$ endocrine and nonendocrine cells.

\section{Models for disease research}

Current model systems limit the research and exploration of diabetes and other disease mechanisms; for example, cell lines respond poorly to glucose stimulation and cannot model interactions between $\beta$ cells and other cell types, which may play roles in islet function and the onset of diabetes. Islet organoids provide a novel system in which to study diabetes. $\beta$ cells in islets are destroyed during disease progression in T1D and thus were previously difficult to be studied. Currently, iPSCs derived from patients with T1D are used to generate new models demonstrating that cells respond to different forms of $\beta$ cell stress in vitro (Millman et al., 2016). Analysis of three T2D-related genes, CDKAL1, $K C N Q 1$, and KCNJ11, which were identified by GWAS, in gene-edited hESCs showed normal endocrine specification but impaired insulin secretion in vitro and in vivo (Zeng et al., 2016). These phenotypes mimicked symptoms in patients carrying mutations in these genes, whereas animal models showed irrelevant phenotypes (Asahara et al., 2015). Wolfram syndrome, an autosomal recessive disease caused by mutations in WFS1, is characterized by juvenile-onset diabetes (Rohayem et al., 2011). $\beta$-like cells differentiated from iPSCs derived from Wolfram syndrome patients showed decreased insulin content and increased activity of molecules related to endoplasmic reticulum (ER) stress, indicating that $\beta$ cell failure is caused by WFS1 deficiency (Shang et al., 2014; Maxwell et al., 2020). Congenital hyperinsulinism $(\mathrm{CHI})$, a rare genetic disorder related to mutations in sulfonylurea receptor 1 (SUR1), encoded by $A B C C 8$, is characterized by excessive insulin secretion and hypoglycemia (Nessa et al., 2015). ABCC8-deficient sc- $\beta$ cells recapitulated the disease phenotypes of $\mathrm{CHI}$ in vitro, indicating that these cells could be an attractive model for further elucidating SUR1 function (Guo et al., 2017). We have summarized the disease models related to islet organoids and sc- $\beta$ cells in Table 1.

\section{Platforms for drug screening}

Islet organoids are better platforms than other models for drug screening in diabetes. Via a chemical drug library, T5224 was discovered to be able to rescue $\beta$ cell dysfunction in CDKAL1 $1^{-1-} \mathrm{sc}-\beta$ cells by inhibiting the FOS/JUN pathway, providing a potential treatment for T2D (Zeng et al., 2016). Induction of GLIS3 $^{-1-}$ hESCs showed impaired $\beta$ cell differentiation and increased apoptosis. Moreover, a highcontent chemical screening based on $\mathrm{GLIS3}^{-1-}$ hESCs derivatives identified a drug candidate, galunisertib, that could be used for treatment of GLIS3-associated diabetes (Amin et al., 2018). 
Table 1. Representative studies establishing islet organoids as disease models and drug screening platforms

\begin{tabular}{|c|c|c|c|c|c|}
\hline Genes & $\begin{array}{l}\text { Related types of } \\
\text { diabetes/ } \\
\text { Symptoms of } \\
\text { patients }\end{array}$ & $\begin{array}{l}\text { Derivation of } \\
\text { islet organoids }\end{array}$ & Phenotypes of islet organoids & $\begin{array}{l}\text { Drug/ } \\
\text { Chemical } \\
\text { screening }\end{array}$ & References \\
\hline $\begin{array}{l}\text { Non- } \\
\text { specific }\end{array}$ & T1D & $\begin{array}{l}\text { Patients- } \\
\text { derived }\end{array}$ & $\begin{array}{l}\text { Resemble human islets; normal } \\
\text { GSIS }\end{array}$ & $\begin{array}{l}\text { Not } \\
\text { mentioned }\end{array}$ & $\begin{array}{l}\text { (Manzar et al., } \\
\text { 2017) }\end{array}$ \\
\hline $\begin{array}{l}\text { Non- } \\
\text { specific }\end{array}$ & T1D & $\begin{array}{l}\text { Patients- } \\
\text { derived }\end{array}$ & $\begin{array}{l}\text { Respond to glucose in vitro and } \\
\text { in vivo }\end{array}$ & $\begin{array}{r}\text { Tolbutamide; } \\
\text { Liraglutide; } \\
\text { LY2608204 }\end{array}$ & $\begin{array}{l}\text { (Millman } \\
\text { et al., 2016) }\end{array}$ \\
\hline $\begin{array}{l}\text { Non- } \\
\text { specific }\end{array}$ & T1D & $\begin{array}{l}\text { Patients- } \\
\text { derived }\end{array}$ & $\begin{array}{l}\text { T cell activation and killing when sc- } \\
\beta \text { cells were co-cultured with } \\
\text { autologous PBMCs }\end{array}$ & $\begin{array}{l}\text { Not } \\
\text { mentioned }\end{array}$ & $\begin{array}{l}\text { (Leite et al., } \\
\text { 2020) }\end{array}$ \\
\hline RNLS & T1D & $\begin{array}{l}\text { KO and WT } \\
\text { hiPSCs }\end{array}$ & $\begin{array}{l}\text { Resistance to thapsigargin-induced } \\
\text { apoptosis }\end{array}$ & pargyline & $\begin{array}{l}\text { (Cai et al., } \\
2020)\end{array}$ \\
\hline CDKAL1 & $\mathrm{T} 2 \mathrm{D}$ & KO hESCs & $\begin{array}{l}\text { Defective insulin secretion; } \\
\text { hypersensitivity to } \\
\text { glucolipotoxicity }\end{array}$ & T5224 & $\begin{array}{l}\text { (Zeng et al., } \\
\text { 2016) }\end{array}$ \\
\hline GSTT1 & $\begin{array}{l}\text { Increased risk to } \\
\text { T2D }\end{array}$ & KO hESCs & $\begin{array}{l}\text { Hypersensitive to propargite (a } \\
\text { pesticide causing } \beta \text { cell death) }\end{array}$ & $\begin{array}{l}\text { Not } \\
\text { mentioned }\end{array}$ & $\begin{array}{l}\text { (Zhou et al., } \\
\text { 2018) }\end{array}$ \\
\hline KCNQ1 & $\mathrm{T} 2 \mathrm{D}$ & KO hESCs & Defective insulin secretion & $\begin{array}{l}\text { Not } \\
\text { mentioned }\end{array}$ & $\begin{array}{l}\text { (Zeng et al., } \\
\text { 2016) }\end{array}$ \\
\hline KCNJ11 & $\mathrm{T} 2 \mathrm{D}$ & KO hESCs & Defective insulin secretion & $\begin{array}{l}\text { Not } \\
\text { mentioned }\end{array}$ & $\begin{array}{l}\text { (Zeng et al., } \\
\text { 2016) }\end{array}$ \\
\hline SIX2 & $\mathrm{T} 2 \mathrm{D}$ & $\begin{array}{l}\mathrm{KD} \text { and } \mathrm{KO} \\
\mathrm{hESCs}\end{array}$ & Impaired GSIS & $\begin{array}{l}\text { Not } \\
\text { mentioned }\end{array}$ & $\begin{array}{r}\text { (Velazco-Cruz } \\
\text { et al., 2020) }\end{array}$ \\
\hline $\begin{array}{l}\text { SLC30A8 } \\
(p . \\
\left.\operatorname{Arg} 138^{*}\right)\end{array}$ & $\begin{array}{l}\text { Resistance to } \\
\text { T2D }\end{array}$ & Mutant hiPSCs & $\begin{array}{l}\text { Reduced formation of } \beta \text { like cells; } \\
\text { SLC30A8 expression } \\
\text { haploinsufficiency }\end{array}$ & $\begin{array}{l}\text { Not } \\
\text { mentioned }\end{array}$ & $\begin{array}{l}\text { (Dwivedi } \\
\text { et al., 2019) }\end{array}$ \\
\hline VDR & $\mathrm{T} 2 \mathrm{D}$ & KD hiPSCs & $\begin{array}{l}\text { Increased cytokine-induced } \\
\text { cell death }\end{array}$ & Cal + iBRD9 & $\begin{array}{l}\text { (Wei et al., } \\
\text { 2018) }\end{array}$ \\
\hline HNF4A & MODY1 & $\begin{array}{l}\text { Patients- } \\
\text { derived }\end{array}$ & $\begin{array}{l}\text { No specific phenotypes compared } \\
\text { to hESC-derived } \beta \text { like cells }\end{array}$ & $\begin{array}{l}\text { Not } \\
\text { mentioned }\end{array}$ & $\begin{array}{l}\text { (Vethe et al., } \\
\text { 2017) }\end{array}$ \\
\hline HNF1A & MODY3 & KO hESCs & $\begin{array}{l}\text { Impaired GSIS; } \alpha \text {-cell preference in } \\
\text { islet development }\end{array}$ & $\begin{array}{l}\text { Not } \\
\text { mentioned }\end{array}$ & $\begin{array}{l}\text { (Cardenas- } \\
\text { Diaz et al., } \\
\text { 2019) }\end{array}$ \\
\hline HNF1B & MODY5 & $\begin{array}{l}\text { Patients- } \\
\text { derived }\end{array}$ & $\begin{array}{l}\text { Retardation of cell growth; mutant } \\
\text { mRNA degradation }\end{array}$ & $\begin{array}{l}\text { Not } \\
\text { mentioned }\end{array}$ & $\begin{array}{l}\text { (Yabe et al., } \\
\text { 2015) }\end{array}$ \\
\hline NEUROD1 & MODY6, ND & Mutant hESCs & Impaired $\beta$ cell differentiation & $\begin{array}{l}\text { Not } \\
\text { mentioned }\end{array}$ & $\begin{array}{l}\text { (Romer et al., } \\
\text { 2019) }\end{array}$ \\
\hline GATA4 & $\begin{array}{l}\text { ND and } \\
\text { pancreatic } \\
\text { agenesis }\end{array}$ & KO hESCs & $\begin{array}{l}\text { Impaired pancreatic progenitor } \\
\text { formation }\end{array}$ & $\begin{array}{l}\text { Not } \\
\text { mentioned }\end{array}$ & $\begin{array}{l}\text { (Shi et al., } \\
\text { 2017) }\end{array}$ \\
\hline GATA6 & $\begin{array}{l}\text { ND and } \\
\text { pancreatic } \\
\text { agenesis }\end{array}$ & $\begin{array}{l}\text { KO and mutant } \\
\text { hESCs and } \\
\text { hiPSCs }\end{array}$ & $\begin{array}{l}\text { Haploinsufficient requirement of } \\
\text { GATA6 in pancreatic progenitors } \\
\text { and } \beta \text { cells development }\end{array}$ & $\begin{array}{l}\text { Not } \\
\text { mentioned }\end{array}$ & $\begin{array}{l}\text { (Shi et al., } \\
\text { 2017) }\end{array}$ \\
\hline GLIS3 & ND, T1D, T2D & KO hESCs & $\begin{array}{l}\text { Impaired } \beta \text { cell formation; increased } \\
\text { apoptosis }\end{array}$ & Galunisertib & $\begin{array}{l}\text { (Amin et al., } \\
\text { 2018) }\end{array}$ \\
\hline $\begin{array}{l}\text { INS } \\
\text { (mutation } \\
\text { C96R, } \\
\text { C109Y } \\
\text { and } \\
\text { ATG>ATA) }\end{array}$ & ND & $\begin{array}{l}\text { Patients- } \\
\text { derived (with } \\
\text { or without } \\
\text { mutation } \\
\text { correction) }\end{array}$ & $\begin{array}{l}\text { ER stress; reduced proliferation of } \\
\beta \text { cells; reduced insulin secretion } \\
\text { and increased } \alpha \text { cell mass in vivo; } \\
\text { rescued by mutation correction }\end{array}$ & $\begin{array}{l}\text { Not } \\
\text { mentioned }\end{array}$ & $\begin{array}{l}\text { (Balboa et al., } \\
\text { 2018; Ma } \\
\text { et al., 2018) }\end{array}$ \\
\hline
\end{tabular}


Table 1 continued

\begin{tabular}{|c|c|c|c|c|c|}
\hline Genes & $\begin{array}{l}\text { Related types of } \\
\text { diabetes/ } \\
\text { Symptoms of } \\
\text { patients }\end{array}$ & $\begin{array}{l}\text { Derivation of } \\
\text { islet organoids }\end{array}$ & Phenotypes of islet organoids & $\begin{array}{l}\text { Drug/ } \\
\text { Chemical } \\
\text { screening }\end{array}$ & References \\
\hline NGN3 & $\begin{array}{r}\text { ND (some } \\
\text { patients) }\end{array}$ & $\begin{array}{l}\text { KO hESCs and } \\
\text { induced } \\
\text { mutant } \\
\text { expression in } \\
\text { hESCs } \\
\text { derivatives }\end{array}$ & $\begin{array}{l}\text { No functional endocrine formation } \\
\text { in KO hESCs, which was rescued } \\
\text { by hypomorphic mutants. }\end{array}$ & $\begin{array}{l}\text { Not } \\
\text { mentioned }\end{array}$ & $\begin{array}{l}\text { (McGrath } \\
\text { et al., 2015; } \\
\text { Zhu et al., } \\
\text { 2016; } \\
\text { Zhang et al., } \\
\text { 2019) }\end{array}$ \\
\hline$P D X 1$ & ND & KO hESCs & $\begin{array}{l}\text { Haploinsufficient requirement for } \\
\text { PDX1 in } \beta \text { cell differentiation }\end{array}$ & $\begin{array}{l}\text { Not } \\
\text { mentioned }\end{array}$ & $\begin{array}{l}\text { (Zhu et al., } \\
\text { 2016) }\end{array}$ \\
\hline$R F X$ & ND & KO hESCs & $\begin{array}{l}\text { Impaired pancreatic progenitor } \\
\text { formation }\end{array}$ & $\begin{array}{l}\text { Not } \\
\text { mentioned }\end{array}$ & $\begin{array}{l}\text { (Zhu et al., } \\
\text { 2016) }\end{array}$ \\
\hline STAT3 & $\begin{array}{l}\text { ND and } \\
\text { pancreatic } \\
\text { hypoplasia }\end{array}$ & $\begin{array}{l}\text { Patients- } \\
\text { derived (with } \\
\text { or without } \\
\text { mutation } \\
\text { correction) }\end{array}$ & $\begin{array}{l}\text { Premature differentiation of } \\
\text { pancreatic } \\
\text { progenitors; pancreatic hypoplasia; } \\
\text { increased } \alpha \text { cell mass in vivo; } \\
\text { rescued by mutation correction }\end{array}$ & $\begin{array}{l}\text { Not } \\
\text { mentioned }\end{array}$ & $\begin{array}{l}\text { (Saarimaki- } \\
\text { Vire et al., } \\
\text { 2017) }\end{array}$ \\
\hline$A B C C 8$ & $\begin{array}{l}\text { Congenital } \\
\text { hyperinsulinism } \\
\text { and } \\
\text { hypoglycemia }\end{array}$ & KO hESCs & Excess insulin secretion & $\begin{array}{l}\text { Nifedipine, } \\
\text { octreotide, } \\
\text { nicorandil }\end{array}$ & $\begin{array}{l}\text { (Guo et al., } \\
2017 \text { ) }\end{array}$ \\
\hline FOXA2 & $\begin{array}{l}\text { Various types of } \\
\text { diabetes }\end{array}$ & KO hESCs & $\begin{array}{l}\text { Impaired pancreatic progenitor } \\
\text { formation }\end{array}$ & $\begin{array}{l}\text { Not } \\
\text { mentioned }\end{array}$ & $\begin{array}{l}\text { (Lee et al., } \\
\text { 2019) }\end{array}$ \\
\hline WFS1 & $\begin{array}{l}\text { Wolfram } \\
\text { syndrome }\end{array}$ & $\begin{array}{l}\text { Patients- } \\
\text { derived (with } \\
\text { or without } \\
\text { mutation } \\
\text { correction) }\end{array}$ & $\begin{array}{l}\text { Decreased insulin content; ER } \\
\text { stress; rescued by mutation } \\
\text { correction }\end{array}$ & 4PBA & $\begin{array}{l}\text { (Shang et al., } \\
\text { 2014; } \\
\text { Maxwell } \\
\text { et al., 2020) }\end{array}$ \\
\hline MAFB & Not reported & KO hESCs & $\begin{array}{l}\text { Preference commitment to } \delta \text { or } y \\
\text { cells instead of } \alpha \text { or } \beta \text { cells }\end{array}$ & $\begin{array}{l}\text { Not } \\
\text { mentioned }\end{array}$ & $\begin{array}{l}\text { (Russell et al., } \\
\text { 2020) }\end{array}$ \\
\hline
\end{tabular}

With advances in iPSC technology and personalized medicine, patient-derived $\beta$ cells and islet organoids can serve as informative disease models recapitulating the pathogenesis and phenotypes of specific patients and can be used to assess patient-specific drug reactions upon screening. In a proof-of-concept experiment to evaluate possible applications for drug screening, sc- $\beta$ cells from T1D patient-derived hiPSCs treated with three antidiabetic compounds, tolbutamide, liraglutide and LY2608204, showed increased insulin release (Millman et al., 2016). Additionally, 4PBA successfully restored the glucose responsiveness of islet organoids derived from patients with Wolfram syndrome (Shang et al., 2014). However, the limited functionality and reproducibility of established islet organoids require validation in other systems.

\section{Models for studying infection with SARS-CoV-2 and other viruses}

During the current worldwide COVID-19 pandemic, diabetes has been reported to be a high-risk factor for both SARSCoV-2 infection and severe symptoms in infected patients (Muniyappa and Gubbi, 2020). Significantly increased mortality and comorbidities have been observed in patients with COVID-19 and pre-existing T1D and T2D, and these outcomes can be ameliorated with glycemic control (Zhu et al., 2020). On the other hand, COVID-19 can also induce or worsen hyperglycemia through unclear mechanisms (Bornstein et al., 2020). Hence, islet organoids have potential as a promising human model at the whole-organ level for revealing the mechanisms underlying putative SARS-CoV-2 infection and destruction of pancreatic islets, as well as for assessing therapeutic drugs for both treatment of COVID-19 and glycemic control in the COVID-19 context (Fig. 3). 


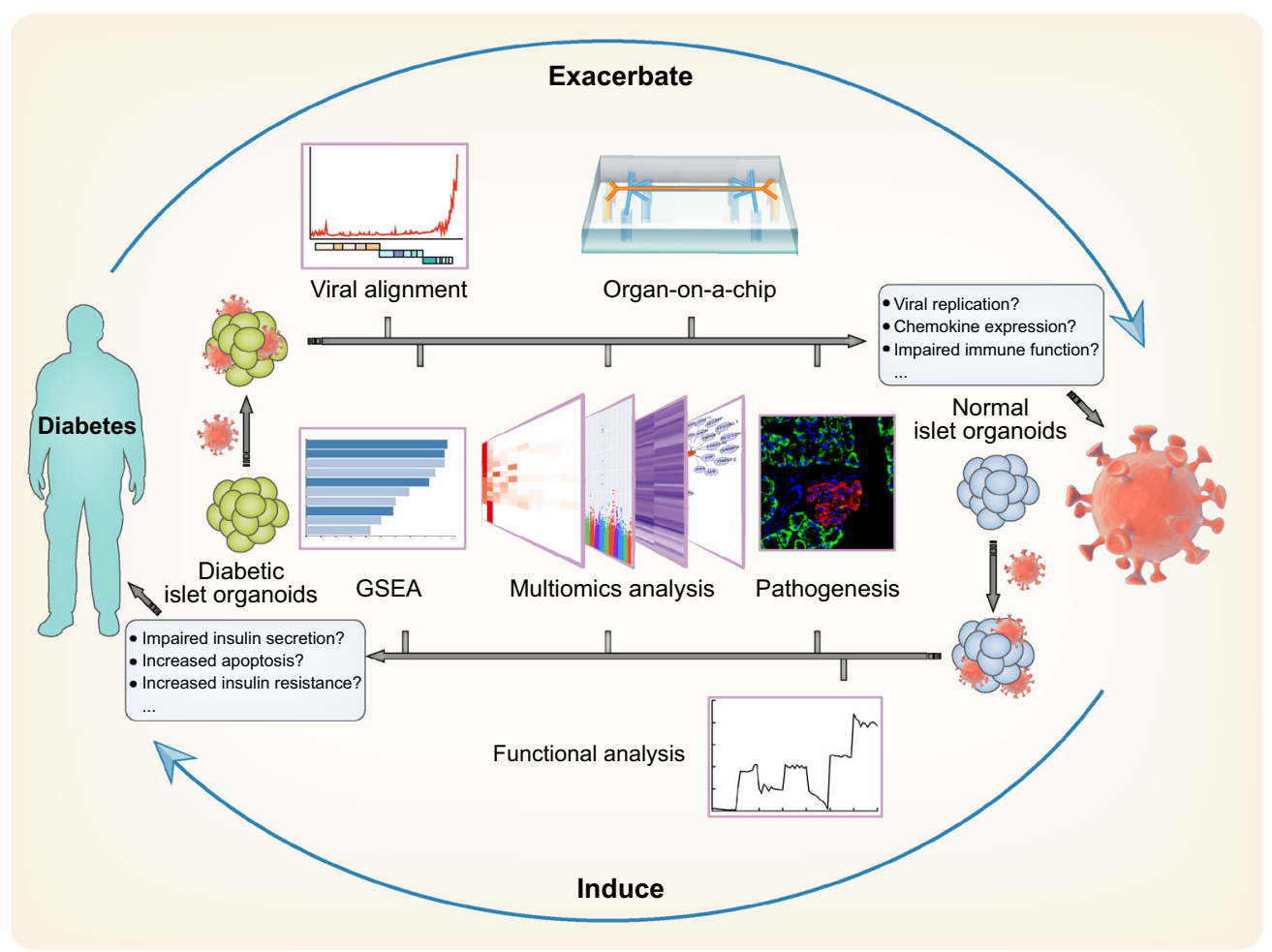

Figure 3. Islet organoids as a promising model for SARS-CoV-2 infection. Evaluation of SARS-CoV-2-infected diabetic islet organoids may elucidate the mechanisms underlying the elevated mortality in diabetic COVID-19 patients. Identification of islet dysfunction in SARS-CoV-2-infected normal islet organoids would help to clarify the onset of diabetes in COVID-19 patients.

As a proof-of-concept experiment, islet organoids and several other organoids were recently used to model SARSCoV-2 infection in various human organs (Han et al., 2020; Lamers et al., 2020; Suzuki et al., 2020; Yang et al., 2020). hESC-derived sc- $\beta$ and sc- $\alpha$ cells expressed the coronavirus spike protein receptor ACE2 and were permissive to SARS$\mathrm{CoV}-2$ infection with robust viral replication in vitro and in vivo, consistent with the results in human primary $\beta$ and $\alpha$ cells, suggesting the authenticity of islet organoids in modeling virus infection (Yang et al., 2020). SARS-CoV-2-infected sc- $\beta$ and sc- $\alpha$ cells showed increased insulin resistance and chemokine expression and a decrease in endocrine functional pathways due to increased apoptosis, resulting in insulin deficiency and even diabetes onset in some COVID-19 patients (Yang et al., 2020). However, the expression of ACE2 is relatively low in endocrine compartments compared with exocrine compartments. Evidence has shown that pancreatic ducts and microvasculature are more likely targets in SARS-CoV-2 infection (Coate et al., 2020; Kusmartseva et al., 2020). Therefore, whether islet organoids are an ideal SARS-CoV-2 infection model remains to be observed and determined. As a safe and convenient system, organ-on-a-chip technology can identify the crosstalk between different SARS-CoV-2-infected organs and elucidate the mechanisms underlying the elevated mortality in diabetic COVID-19 patients.
In addition to SARS-CoV-2, several other viruses are involved in the onset of T1D (Op de Beeck and Eizirik, 2016), and the islet organoid system has shown the capacity to model both virus infection and endocrine cell dysfunction, offering cellular and molecular insights into human-relevant pathogenesis.

Potential organ sources for tissue replacement and personalized therapy

Islet organoids have the potential to overcome the shortage of cadaveric islet donors by offering an unlimited number of functional islets on demand for regenerative therapy. The combination of IPSC and CRISPR technologies makes it possible to derive patient-personalized islet organoids with or without gene correction (Shang et al., 2014; Millman et al., 2016; Saarimaki-Vire et al., 2017; Balboa et al., 2018), paving the way for autologous transplantation and minimizing immune rejection. Compatibility of these methods with novel technology such as PD-L1 generated immune-evasive islet organoids which allows them to offer a new therapeutic strategy for autoimmune diabetes, like T1D (Yoshihara et al., 2020). Recently, phase $1 / I$ clinical trials for subcutaneous implantation of hESC-derived pancreatic endodermal or progenitor cells, which will further mature into functional endocrine cells in vivo, into T1D patients were approved 
(Viacyte, 2014, 2016, 2017a, b, 2019). Different kinds of encapsulation devices have been applied to contain and protect the implanted cells (Cooper-Jones and Ford, 2016). The PEC-Encap (VC-01) prevents immune cell accession from direct contact with the implanted cells, but allows vital nutrients and proteins to travel between the inside cells and the outside blood vessels (Agulnick et al., 2015). The PECDirect (VC-02) allows blood vessels to enter the device and directly interact with the implanted cells, while immune cells are also capable of entering the device (Cooper-Jones and Ford, 2016).

\section{REMAINING CHALLENGES AND PROSPECTIVE SOLUTIONS}

Although improvements have allowed 3D hormone-producing islet organoids to partially reproduce islet morphology and function, certain limitations need to be addressed.

\section{Challenges in the establishment of islet organoids}

Immaturity

Generally, established islet organoids do not fully recapitulate the behavior of native islets at the molecular and functional levels; for example, they have poor insulin secretion ability and lack dynamic insulin release. To improve the performance of islet organoids, one of the key fundamental efforts is characterization of the discrepancies between derived islet organoids and native islets, as well as updating induction strategies. Multiomics analysis approaches, especially single-cell RNA sequencing (scRNA-seq), have widely been used and shown to be informative for revealing molecular defects hindering the maturation and application of islet organoids. The results showed that most derived islet organoids rarely express certain mature $\beta$ cell transcription factors, including MAFA, UCN3 and SIX3, differently express mature $\beta$ cell functional genes, including PCSK1,PCSK2, CPE (Suckale and Solimena, 2010; Wang et al., 2011; Li et al., 2018), and the ratio of major endocrine cells is much different from that of native islets (Bakhti et al., 2019; Veres et al., 2019; Augsornworawat et al., 2020). Real-time imaging of the mouse embryonic pancreas demonstrated how molecular interactions and organ architecture influence the cell fate specification of pancreatic progenitors to commit to endocrine differentiation (Nyeng et al., 2019). Similar studies on islet organoids or native human islets will substantially contribute to the current understanding of islet development.

\section{Heterogeneity}

Currently established islet organoids have lost at least part of the heterogeneity compared with their in vivo counterparts. Although most islet organoids contain all or several of the five major islet cell types, their proportion of $\beta$ cells is much higher than that of native human islets. Human islets contain more non- $\beta$ endocrine cells, which disperse more widely and without a prominent core, than rodent islets (Cabrera et al., 2006; Arrojo e Drigo et al., 2015; Roscioni et al., 2016). In addition, $\beta$ cells are highly heterogeneous and comprise several subpopulations differing in electrical activity, glucose responsiveness, and proliferative activity (Meda et al., 1984; de Vargas et al., 1997; Van de Casteele et al., 2013; Bader et al., 2016; Roscioni et al., 2016). The mechanism and biological relevance of such heterogeneity in humans are not fully understood, and high-fidelity islet organoids may help elucidate this issue. Nonendocrine supporting cells, including endothelial cells and neurons, are also barely observed in current islet organoids. These supporting cells are essential components that form vascular and innervation networks, which facilitate islet development by integrating islets into the circulatory and nervous systems (Ahren, 2000; Ranjan et al., 2009; Borden et al., 2013). Incorporation of supporting cells in islet organoids may not only improve the maturity and functionality of the derived islet organoids but also contribute to identifying the interactions between different cell types in human islets. Vascularized islet organoids have been attempted by several elaborate strategies (summarized above); however, innervated islet organoids still need to be pursued in the future.

Islet organoids have certain undesired heterogeneity. ScRNA-seq revealed that most derived islet organoids comprise large numbers of proliferating progenitors or precursors and irrelevant or uncharacterized cell types (Veres et al., 2019; Weng et al., 2020), which hinders their in vitro application and in vivo transplantation. Elimination of such undesired heterogeneity requires either improvement of the induction efficiency or cell isolation to remove the unwanted populations and enrich the endocrine populations. CD49a has been identified as a surface marker for sc- $\beta$ cells and used to purify $\beta$-like cells (Veres et al., 2019). GP2 has been determined to be a surface marker for $\mathrm{PDX} 1^{+} / \mathrm{NKX} 6.1^{+}$ pancreatic progenitors. This protein has been employed to enrich $\mathrm{PDX} 1^{+} / \mathrm{NKX} 6.1^{+}$cells, eliminate $\sim 20 \%-40 \%$ of undifferentiated hPSCs, early derivatives or irrelevant cell types, and generate a higher percentage of $\beta$ - and $\alpha$-like cells (Ameri et al., 2017; Cogger et al., 2017). Other innovative strategies to remove the undesired products have been introduced to avoid teratoma formation after transplantation and to indirectly elevate induction efficiency. Insertion of the suicide gene iC9 in the SOX2 locus enabled induction of apoptosis of undifferentiated hPSCs upon treatment of the final-stage products with the iC9 inducer AP1903, while the differentiated hPSC derivatives were unaffected (Wu et al., 2019).

\section{Batch-to-batch variations}

Batch-to-batch variations in the efficiency of differentiation, organoid quality (e.g., size and shape), and organoid viability or functionality are significant. This stochasticity reflects the absence of pivotal niche signals in the culture cocktail; thus, a complete and detailed understanding of the islet 
development process is required to optimize growth factor cocktail recipes. Additionally, cell-specific subtle modifications of induction strategies are needed, especially for patient-derived iPSCs. iPSCs derived from patients with T1D lost resistance to differentiation after transient demethylation treatment (Manzar et al., 2017). The demethylation-treated sc- $\beta$ cells displayed no significant disparities compared with sc- $\beta$ cells derived from healthy individuals, highlighting the necessity of cell-specific induction strategies (Manzar et al., 2017).

\section{Challenges in the clinical applications of islet organoids}

Islet organoids have shown potential as an organ source for the treatment of diabetes. However, several issues related to islet organoid transplantation must be carefully addressed.

\section{Tumorigenicity}

Although iPSCs show promise for personalized therapy, their issues with clinical safety remain to be addressed. The incorporation of stem cell derivatives in the human body raises concerns with respect to tumors (Zhu and Fan, 2018), especially teratoma formation, which is further exacerbated by the presence of uncharacterized proliferative cells in established organoids. The propensity for teratoma formation from iPSC derivatives has been reported to be affected by many factors, including iPSC tissue origin and strategies used for reprogramming, differentiation or transplantation (Miura et al., 2009). For example, c-Myc, an indispensable transcription factor in the reprogramming cocktail, is an oncogene (Okita et al., 2007). If it is omitted during the reprogramming, iPSCs would be generated with low efficiency (Nakagawa et al., 2010). Thus, prudent selection of induction strategies and rigorous examination before transplantation are indispensable.

\section{Low survival and immunogenicity}

Low survival and limited duration of euglycemia after transplantation have hindered transplantation of both donor islets to patients and islet organoids to mice. Low vascularization and immune rejection have accounted for significant islet cell loss. To overcome these issues, scientists have proposed elaborate encapsulation devices to shelter organoids from the immune system. Embedding a catheter into subcutaneous tissues at the transplant site in host mice before islet implantation can generate a vascularized space (Pepper et al., 2015). In addition, a recent study proposed using CRISPR/Cas 9 to reduce the immunogenicity of stem cells by eliminating the expression of human leukocyte antigen (HLA) (Han et al., 2019).

\section{Undefined ingredients and contamination}

Most established islet organoids rely on Matrigel. However, Matrigel is not an approved material for clinical applications due to the presence of undefined ingredients. Some groups also use mouse embryonic fibroblasts (MEFs) as feeders for hPSC passaging or fetal bovine serum (FBS) during differentiation, thus resulting in xenogeneic contamination. The influence of xenogeneic contamination and undefined ingredients on the cellular microenvironment and organoid morphology or function remains unclear. To render the induced products amenable to transplantation, organoids need to be fully purified by enzymatic digestion to remove scaffolds (Wang et al., 2017; Rossen et al., 2020). Another strategy is culture of the organoids in medical grade scaffolds, either derived from decellularized porcine tissues (Giobbe et al., 2019) or synthesized with defined components. Various kinds of hydrogels, including PEG-based hydrogels functionalized with laminin (Greggio et al., 2013), PLG scaffolds containing exendin-4 microparticles (Kasputis et al., 2018), and electrospun PLLA/PVA scaffolds (Ojaghi et al., 2019), have been developed to facilitate islet or $\beta$ cell specification and maturation, substantially accelerating the clinical applications of islet organoids.

\section{SUMMARY AND PERSPECTIVES}

Islet organoids enable scientists to transform the understanding and treatment of diabetes. An ideal islet organoid should recapitulate the features of islet development and function of mature islets under physiological and pathological conditions. To improve the performance of current islet organoids, a more detailed understanding of islet development is necessary, and interdisciplinary methods, including organ-on-a-chip, 3D scaffold or bioprinting, are welcomed to construct more appropriate physiological niches for islet organoid development. As a highly expected application, islet organoids are considered an unlimited organ resource for transplantation and the treatment of diabetes, although several issues and safety concerns regarding organoid transplantation remain to be addressed. Organ transplantation techniques dedicated to reducing host immune rejection are also evolving (O'Sullivan et al., 2011; Pathak et al., 2019). The development of islet organoids will be a milestone in understanding and treating diabetes.

\section{ACKNOWLEDGEMENTS}

We apologize to the scientists in this field, whose publications were not cited due to space limitations. This work was supported by grants from the Ministry of Science and Technology of the People's Republic of China (2018YFA0507101, 2016YFA0500203), the National Natural Science Foundation of China (31770900, 31730054), the Beijing Natural Science Foundation (5212016), and the Youth Innovation Promotion Association of the Chinese Academy of Sciences (2011087).

\section{AUTHORS' CONTRIBUTIONS}

All authors participated in the design and discussion of manuscript conception and outline, contributed to editing of the draft manuscript. 


\section{COMPLIANCE WITH ETHICS GUIDELINES}

All the authors of this paper declare that they have no conflict of interest. This article does not contain any studies with human or animal subjects performed by the any of the authors.

\section{ABBREVIATIONS}

2D, two-dimensional; 3D, three-dimensional; ACE2, angiotensinconverting enzyme 2; ASC, adult stem cells; ATP, adenosine triphosphate; BMP, bone morphogenetic protein; Cas9, CRISPRassociated protein 9; $\mathrm{CHI}$, congenital hyperinsulinism; COVID-19, coronavirus disease 2019; CRISPR, clustered regularly interspaced short palindromic repeats; $D E$, definitive endoderm; EB, embryonic bodies; ECC, endocrine cell clusters; ECM, extracellular matrix; EP, endocrine precursors; ER, endoplasmic reticulum; ESC, embryonic stem cells; FBS, fetal bovine serum; GCG, glucagon; GHRL, ghrelin; GSEA, gene set enrichment analysis; GSIS, glucose-stimulated insulin secretion; GWAS, genome-wide association studies; HLA, human leukocyte antigen; HUVEC, human umbilical vein endothelial cells; iC9, inducible caspsae-9; INS, insulin; iPSC, induced pluripotent stem cells; LIF, leukemia inhibitory factor; MEF, mouse embryonic fibroblast; MODY, maturity-onset diabetes of the young; MSC, mesenchymal stem cells; ND, neonatal diabetes; PBMC, peripheral blood mononuclear cell; PdBU, phorbol 12,13-dibutyrate; PEG, polyethylene glycol; PEGDE, polyethyleneglycol diglycidyl ether; PGK, phosphoglycerate kinase; PKC, protein kinase C; PLG, polylactide-co-glycolide; PLLA/PVA, poly-l-lactic acid/polyvinyl alcohol; PP, pancreatic progenitors; PPY, pancreatic polypeptide; PSC, pluripotent stem cells; SARS-CoV-2, severe acute respiratory syndrome coronavirus 2 ; sc- $\beta$, stem-cell-derived $\beta$ cells; scRNA-seq, single-cell RNA sequencing; SST, somatostatin; SUR1, sulfonylurea receptor 1; T1D, type 1 diabetes; T2D, type 2 diabetes; TALEN, transcription activator-like effector nucleases; TGF, transforming growth factor; VDR, vitamin D receptor; VEGFA, vascular endothelial growth factor $A$.

\section{OPEN ACCESS}

This article is licensed under a Creative Commons Attribution 4.0 International License, which permits use, sharing, adaptation, distribution and reproduction in any medium or format, as long as you give appropriate credit to the original author(s) and the source, provide a link to the Creative Commons licence, and indicate if changes were made. The images or other third party material in this article are included in the article's Creative Commons licence, unless indicated otherwise in a credit line to the material. If material is not included in the article's Creative Commons licence and your intended use is not permitted by statutory regulation or exceeds the permitted use, you will need to obtain permission directly from the copyright holder. To view a copy of this licence, visit http:// creativecommons.org/licenses/by/4.0/.

\section{REFERENCES}

Aamodt KI, Powers AC (2017) Signals in the pancreatic islet microenvironment influence beta-cell proliferation. Diabetes Obes Metab 19(Suppl 1):124-136

Aguayo-Mazzucato C, Bonner-Weir S (2018) Pancreatic beta cell regeneration as a possible therapy for diabetes. Cell Metab 27:57-67

Agulnick AD, Ambruzs DM, Moorman MA, Bhoumik A, Cesario RM, Payne JK, Kelly JR, Haakmeester C, Srijemac R, Wilson AZ et al (2015) Insulin-producing endocrine cells differentiated in vitro from human embryonic stem cells function in macroencapsulation devices in vivo. Stem Cells Transl Med 4:1214-1222

Ahren B (2000) Autonomic regulation of islet hormone secretionimplications for health and disease. Diabetologia 43:393-410

Alvarez-Dominguez JR, Donaghey J, Rasouli N, Kenty JHR, Helman A, Charlton J, Straubhaar JR, Meissner A, Melton DA (2020) Circadian entrainment triggers maturation of human in vitro islets. Cell Stem Cell 26(108-122):e110

Ameri J, Borup R, Prawiro C, Ramond C, Schachter KA, Scharfmann R, Semb H (2017) Efficient generation of glucose-responsive beta cells from isolated GP2(+) human pancreatic progenitors. Cell Rep 19:36-49

Amin S, Cook B, Zhou T, Ghazizadeh Z, Lis R, Zhang T, Khalaj M, Crespo M, Perera M, Xiang JZ et al (2018) Discovery of a drug candidate for GLIS3-associated diabetes. Nat Commun 9:2681

Arrojo e Drigo R, Ali Y, Diez J, Srinivasan DK, Berggren PO, Boehm BO (2015) New insights into the architecture of the islet of Langerhans: a focused cross-species assessment. Diabetologia 58:2218-2228

Asahara $\mathrm{S}$, Etoh $\mathrm{H}$, Inoue $\mathrm{H}$, Teruyama $\mathrm{K}$, Shibutani $\mathrm{Y}$, Ihara $\mathrm{Y}$, Kawada Y, Bartolome A, Hashimoto N, Matsuda T et al (2015) Paternal allelic mutation at the Kcnq1 locus reduces pancreatic beta-cell mass by epigenetic modification of Cdkn1c. Proc Natl Acad Sci USA 112:8332-8337

Ashcroft FM, Rorsman P (2012) Diabetes mellitus and the beta cell: the last ten years. Cell 148:1160-1171

Augsornworawat P, Maxwell KG, Velazco-Cruz L, Millman JR (2020) Single-cell transcriptome profiling reveals beta cell maturation in stem cell-derived islets after transplantation. Cell Rep 32:108067

Bader E, Migliorini A, Gegg M, Moruzzi N, Gerdes J, Roscioni SS, Bakhti M, Brandl E, Irmler M, Beckers J et al (2016) Identification of proliferative and mature beta-cells in the islets of Langerhans. Nature 535:430-434

Bakhti M, Scheibner K, Tritschler S, Bastidas-Ponce A, TarquisMedina M, Theis FJ, Lickert H (2019) Establishment of a highresolution $3 \mathrm{D}$ modeling system for studying pancreatic epithelial cell biology in vitro. Mol Metab 30:16-29

Balboa D, Saarimaki-Vire J, Borshagovski D, Survila M, Lindholm P, Galli E, Eurola S, Ustinov J, Grym H, Huopio H et al (2018) Insulin mutations impair beta-cell development in a patient-derived iPSC model of neonatal diabetes. Elife 7

Basford CL, Prentice KJ, Hardy AB, Sarangi F, Micallef SJ, Li X, Guo Q, Elefanty AG, Stanley EG, Keller G et al (2012) The functional and molecular characterisation of human embryonic stem cellderived insulin-positive cells compared with adult pancreatic beta cells. Diabetologia 55:358-371 
Bi H, Ye K, Jin S (2020) Proteomic analysis of decellularized pancreatic matrix identifies collagen $\mathrm{V}$ as a critical regulator for islet organogenesis from human pluripotent stem cells. Biomaterials 233:119673

Bishay RH, Greenfield JR (2016) A review of maturity onset diabetes of the young (MODY) and challenges in the management of glucokinase-MODY. Med J Aust 205:480-485

Borden P, Houtz J, Leach SD, Kuruvilla R (2013) Sympathetic innervation during development is necessary for pancreatic islet architecture and functional maturation. Cell Rep 4:287-301

Bornstein SR, Rubino F, Khunti K, Mingrone G, Hopkins D, Birkenfeld AL, Boehm B, Amiel S, Holt RIG, Skyler JS et al (2020) Practical recommendations for the management of diabetes in patients with COVID-19. Lancet Diabetes Endocrinol 8:546-550

Brissova M, Fowler MJ, Nicholson WE, Chu A, Hirshberg B, Harlan DM, Powers AC (2005) Assessment of human pancreatic islet architecture and composition by laser scanning confocal microscopy. J Histochem Cytochem 53:1087-1097

Broda TR, McCracken KW, Wells JM (2019) Generation of human antral and fundic gastric organoids from pluripotent stem cells. Nat Protoc 14:28-50

Bruin JE, Erener S, Vela J, Hu X, Johnson JD, Kurata HT, Lynn FC, Piret JM, Asadi A, Rezania A et al (2014) Characterization of polyhormonal insulin-producing cells derived in vitro from human embryonic stem cells. Stem Cell Res 12:194-208

Cabrera O, Berman DM, Kenyon NS, Ricordi C, Berggrern PO, Caicedo A (2006) The unique cytoarchitecture of human pancreatic islets has implications for islet cell function. Proc Natl Acad Sci USA 103:2334-2339

Cai EP, Ishikawa Y, Zhang W, Leite NC, Li J, Hou S, Kiaf B, HollisterLock J, Yilmaz NK, Schiffer CA et al (2020) Genome-scale in vivo CRISPR screen identifies RNLS as a target for beta cell protection in type 1 diabetes. Nat Metab 2:934-945

Candiello J, Grandhi TSP, Goh SK, Vaidya V, Lemmon-Kishi M, Eliato KR, Ros R, Kumta PN, Rege K, Banerjee I (2018) 3D heterogeneous islet organoid generation from human embryonic stem cells using a novel engineered hydrogel platform. Biomaterials 177:27-39

Cardenas-Diaz FL, Osorio-Quintero C, Diaz-Miranda MA, Kishore S, Leavens K, Jobaliya C, Stanescu D, Ortiz-Gonzalez X, Yoon C, Chen CS et al (2019) Modeling monogenic diabetes using human ESCs reveals developmental and metabolic deficiencies caused by mutations in HNF1A. Cell Stem Cell 25(273-289):e275

Chen YJ, Finkbeiner SR, Weinblatt D, Emmett MJ, Tameire F, Yousefi M, Yang C, Maehr R, Zhou Q, Shemer R et al (2014) De novo formation of insulin-producing "neo-beta cell islets" from intestinal crypts. Cell Rep 6:1046-1058

Choi KM, Seo YK, Yoon HH, Song KY, Kwon SY, Lee HS, Park JK (2008) Effect of ascorbic acid on bone marrow-derived mesenchymal stem cell proliferation and differentiation. J Biosci Bioeng 105:586-594

Clevers H (2016) Modeling development and disease with organoids. Cell 165:1586-1597

Coate KC, Cha J, Shrestha S, Wang W, Goncalves LM, Almaca J, Kapp ME, Fasolino M, Morgan A, Dai C et al (2020) SARS-CoV-2 cell entry factors ACE2 and TMPRSS2 are expressed in the microvasculature and ducts of human pancreas but are not enriched in beta cells. Cell Metab 32(1028-1040):e1024

Cogger KF, Sinha A, Sarangi F, McGaugh EC, Saunders D, Dorrell C, Mejia-Guerrero S, Aghazadeh Y, Rourke JL, Screaton RA et al (2017) Glycoprotein 2 is a specific cell surface marker of human pancreatic progenitors. Nat Commun 8:331

Cooper-Jones B, Ford C (2016) Islet cell replacement therapy for insulin-dependent diabetes. In: CADTH Issues in Emerging Health Technologies (Ottawa (ON)), pp 1-9

D'Amour KA, Bang AG, Eliazer S, Kelly OG, Agulnick AD, Smart NG, Moorman MA, Kroon E, Carpenter MK, Baetge EE (2006) Production of pancreatic hormone-expressing endocrine cells from human embryonic stem cells. Nat Biotechnol 24:1392-1401

Davis JC, Alves TC, Helman A, Chen JC, Kenty JH, Cardone RL, Liu DR, Kibbey RG, Melton DA (2020) Glucose response by stem cell-derived beta cells in vitro is inhibited by a bottleneck in glycolysis. Cell Rep 31:107623

de Vargas LM, Sobolewski J, Siegel R, Moss LG (1997) Individual beta cells within the intact islet differentially respond to glucose. J Biol Chem 272:26573-26577

Dominguez-Bendala J, Qadir MMF, Pastori RL (2019) Pancreatic progenitors: there and back again. Trends Endocrinol Metab 30:4-11

Dor Y, Brown J, Martinez OI, Melton DA (2004) Adult pancreatic beta-cells are formed by self-duplication rather than stem-cell differentiation. Nature 429:41-46

Dutta D, Heo I, Clevers H (2017) Disease modeling in stem cellderived 3D organoid systems. Trends Mol Med 23:393-410

Dwivedi OP, Lehtovirta M, Hastoy B, Chandra V, Krentz NAJ, Kleiner S, Jain D, Richard AM, Abaitua F, Beer NL et al (2019) Loss of ZnT8 function protects against diabetes by enhanced insulin secretion. Nat Genet 51:1596-1606

Eberhard D, Kragl M, Lammert E (2010) 'Giving and taking': endothelial and beta-cells in the islets of Langerhans. Trends Endocrinol Metab 21:457-463

Fatehullah A, Tan SH, Barker N (2016) Organoids as an in vitro model of human development and disease. Nat Cell Biol 18:246254

Ghazizadeh Z, Kao DI, Amin S, Cook B, Rao S, Zhou T, Zhang T, Xiang Z, Kenyon R, Kaymakcalan O et al (2017) ROCKII inhibition promotes the maturation of human pancreatic beta-like cells. Nat Commun 8:298

Giobbe GG, Crowley C, Luni C, Campinoti S, Khedr M, Kretzschmar K, De Santis MM, Zambaiti E, Michielin F, Meran L et al (2019) Extracellular matrix hydrogel derived from decellularized tissues enables endodermal organoid culture. Nat Commun 10:5658

Gouzi M, Kim YH, Katsumoto K, Johansson K, Grapin-Botton A (2011) Neurogenin3 initiates stepwise delamination of differentiating endocrine cells during pancreas development. Dev Dyn 240:589-604

Greggio C, De Franceschi F, Figueiredo-Larsen M, Gobaa S, Ranga A, Semb H, Lutolf M, Grapin-Botton A (2013) Artificial threedimensional niches deconstruct pancreas development in vitro. Development 140:4452-4462

Guo D, Liu H, Ruzi A, Gao G, Nasir A, Liu Y, Yang F, Wu F, Xu G, Li YX (2017) Modeling congenital hyperinsulinism with ABCC8- 
deficient human embryonic stem cells generated by CRISPR/ Cas9. Sci Rep 7:3156

Habener JF (2004) A perspective on pancreatic stem/progenitor cells. Pediatr Diabetes 5(Suppl 2):29-37

Han X, Wang M, Duan S, Franco PJ, Kenty JH, Hedrick P, Xia Y, Allen A, Ferreira LMR, Strominger JL et al (2019) Generation of hypoimmunogenic human pluripotent stem cells. Proc Natl Acad Sci USA 116:10441-10446

Han Y, Yang L, Duan X, Duan F, Nilsson-Payant BE, Yaron TM, Wang $P$, Tang $X$, Zhang $T$, Zhao $Z$ et al (2020) Identification of candidate COVID-19 therapeutics using hPSC-derived lung organoids. bioRxiv

Helman A, Cangelosi AL, Davis JC, Pham Q, Rothman A, Faust AL, Straubhaar JR, Sabatini DM, Melton DA (2020) A nutrientsensing transition at birth triggers glucose-responsive insulin secretion. Cell Metab 31(1004-1016):e1005

Hogrebe NJ, Augsornworawat P, Maxwell KG, Velazco-Cruz L, Millman JR (2020) Targeting the cytoskeleton to direct pancreatic differentiation of human pluripotent stem cells. Nat Biotechnol 38:460-470

Hrvatin S, O'Donnell CW, Deng F, Millman JR, Pagliuca FW, Dilorio P, Rezania A, Gifford DK, Melton DA (2014) Differentiated human stem cells resemble fetal, not adult, beta cells. Proc Natl Acad Sci USA 111:3038-3043

Jennings RE, Berry AA, Strutt JP, Gerrard DT, Hanley NA (2015) Human pancreas development. Development 142:3126-3137

Jiang K, Chaimov D, Patel SN, Liang JP, Wiggins SC, Samojlik MM, Rubiano A, Simmons CS, Stabler CL (2019) 3-D physiomimetic extracellular matrix hydrogels provide a supportive microenvironment for rodent and human islet culture. Biomaterials 198:37-48

Johansson KA, Dursun U, Jordan N, Gu G, Beermann F, Gradwohl G, Grapin-Botton A (2007) Temporal control of neurogenin3 activity in pancreas progenitors reveals competence windows for the generation of different endocrine cell types. Dev Cell 12:457465

Kasputis T, Clough D, Noto F, Rychel K, Dye B, Shea LD (2018) Microporous polymer scaffolds for the transplantation of embryonic stem cell derived pancreatic progenitors to a clinically translatable site for the treatment of type I diabetes. ACS Biomater Sci Eng 4:1770-1778

Kelly OG, Chan MY, Martinson LA, Kadoya K, Ostertag TM, Ross KG, Richardson M, Carpenter MK, D'Amour KA, Kroon E et al (2011) Cell-surface markers for the isolation of pancreatic cell types derived from human embryonic stem cells. Nat Biotechnol 29:750-756

Kim Y, Kim H, Ko UH, Oh Y, Lim A, Sohn JW, Shin JH, Kim H, Han YM (2016) Islet-like organoids derived from human pluripotent stem cells efficiently function in the glucose responsiveness in vitro and in vivo. Sci Rep 6:35145

Kroon E, Martinson LA, Kadoya K, Bang AG, Kelly OG, Eliazer S, Young H, Richardson M, Smart NG, Cunningham J et al (2008) Pancreatic endoderm derived from human embryonic stem cells generates glucose-responsive insulin-secreting cells in vivo. Nat Biotechnol 26:443-452

Kunisada Y, Tsubooka-Yamazoe N, Shoji M, Hosoya M (2012) Small molecules induce efficient differentiation into insulin-producing cells from human induced pluripotent stem cells. Stem Cell Res 8:274-284

Kusmartseva I, Wu W, Syed F, Van Der Heide V, Jorgensen M, Joseph P, Tang X, Candelario-Jalil E, Yang C, Nick H et al (2020) Expression of SARS-CoV-2 entry factors in the pancreas of normal organ donors and individuals with COVID-19. Cell Metab 32(1041-1051):e1046

Lamers MM, Beumer J, van der Vaart J, Knoops K, Puschhof J, Breugem TI, Ravelli RBG, Paul van Schayck J, Mykytyn AZ, Duimel HQ et al (2020) SARS-CoV-2 productively infects human gut enterocytes. Science 369:50-54

Lancaster MA, Knoblich JA (2014) Organogenesis in a dish: modeling development and disease using organoid technologies. Science 345:1247125

Lee K, Cho H, Rickert RW, Li QV, Pulecio J, Leslie CS, Huangfu D (2019) FOXA2 is required for enhancer priming during pancreatic differentiation. Cell Rep 28(382-393):e387

Leite NC, Sintov E, Meissner TB, Brehm MA, Greiner DL, Harlan DM, Melton DA (2020) Modeling type 1 diabetes in vitro using human pluripotent stem cells. Cell Rep 32:107894

Lemper M, Leuckx G, Heremans Y, German MS, Heimberg H, Bouwens L, Baeyens L (2015) Reprogramming of human pancreatic exocrine cells to beta-like cells. Cell Death Differ 22:1117-1130

Li M, Du W, Zhou M, Zheng L, Song E, Hou J (2018) Proteomic analysis of insulin secretory granules in INS-1 cells by protein correlation profiling. Biophys Rep 4:329-338

Loomans CJM, Williams Giuliani N, Balak J, Ringnalda F, van Gurp L, Huch M, Boj SF, Sato T, Kester L, de Sousa Lopes SMC et al (2018) Expansion of adult human pancreatic tissue yields organoids harboring progenitor cells with endocrine differentiation potential. Stem Cell Rep 10:712-724

Ma S, Viola R, Sui L, Cherubini V, Barbetti F, Egli D (2018) Beta cell replacement after gene editing of a neonatal diabetes-causing mutation at the insulin locus. Stem Cell Rep 11:1407-1415

Mahaddalkar PU, Scheibner K, Pfluger S, Sterr M, Beckenbauer J, Irmler M, Beckers J, Knobel S, Lickert H (2020) Generation of pancreatic beta cells from CD177(+) anterior definitive endoderm. Nat Biotechnol 38:1061-1072

Mamidi A, Prawiro C, Seymour PA, de Lichtenberg KH, Jackson A, Serup P, Semb H (2018) Mechanosignalling via integrins directs fate decisions of pancreatic progenitors. Nature 564:114-118

Manzar GS, Kim EM, Zavazava N (2017) Demethylation of induced pluripotent stem cells from type 1 diabetic patients enhances differentiation into functional pancreatic beta cells. J Biol Chem 292:14066-14079

Mattsson G (2005) The endothelial cells in islets of langerhans. Ups J Med Sci 110:1-15

Maxwell KG, Augsornworawat P, Velazco-Cruz L, Kim MH, Asada R, Hogrebe NJ, Morikawa S, Urano F, Millman JR (2020) Geneedited human stem cell-derived beta cells from a patient with monogenic diabetes reverse preexisting diabetes in mice. Sci Transl Med 12

McGrath PS, Watson CL, Ingram C, Helmrath MA, Wells JM (2015) The basic helix-loop-helix transcription factor NEUROG3 is required for development of the human endocrine pancreas. Diabetes 64:2497-2505 
Meda P, Atwater I, Goncalves A, Bangham A, Orci L, Rojas E (1984) The topography of electrical synchrony among beta-cells in the mouse islet of Langerhans. Q J Exp Physiol 69:719-735

Memon B, Karam M, Al-Khawaga S, Abdelalim EM (2018) Enhanced differentiation of human pluripotent stem cells into pancreatic progenitors co-expressing PDX1 and NKX6.1. Stem Cell Res Ther 9:15

Millman JR, Xie C, Van Dervort A, Gurtler M, Pagliuca FW, Melton DA (2016) Generation of stem cell-derived beta-cells from patients with type 1 diabetes. Nat Commun 7:11463

Miura K, Okada Y, Aoi T, Okada A, Takahashi K, Okita K, Nakagawa M, Koyanagi M, Tanabe K, Ohnuki M et al (2009) Variation in the safety of induced pluripotent stem cell lines. Nat Biotechnol 27:743-745

Muniyappa R, Gubbi S (2020) COVID-19 pandemic, coronaviruses, and diabetes mellitus. Am J Physiol Endocrinol Metab 318:E736E741

Nair G, Hebrok M (2015) Islet formation in mice and men: lessons for the generation of functional insulin-producing beta-cells from human pluripotent stem cells. Curr Opin Genet Dev 32:171-180

Nair GG, Liu JS, Russ HA, Tran S, Saxton MS, Chen R, Juang C, Li ML, Nguyen VQ, Giacometti S et al (2019) Recapitulating endocrine cell clustering in culture promotes maturation of human stem-cell-derived beta cells. Nat Cell Biol 21:263-274

Nakagawa M, Takizawa N, Narita M, Ichisaka T, Yamanaka S (2010) Promotion of direct reprogramming by transformation-deficient Myc. Proc Natl Acad Sci USA 107:14152-14157

Nessa A, Aziz QH, Thomas AM, Harmer SC, Tinker A, Hussain K (2015) Molecular mechanisms of congenital hyperinsulinism due to autosomal dominant mutations in ABCC8. Hum Mol Genet 24:5142-5153

Nostro MC, Sarangi F, Yang C, Holland A, Elefanty AG, Stanley EG, Greiner DL, Keller G (2015) Efficient generation of NKX6-1+ pancreatic progenitors from multiple human pluripotent stem cell lines. Stem Cell Reports 4:591-604

Nyeng P, Heilmann S, Lof-Ohlin ZM, Pettersson NF, Hermann FM, Reynolds AB, Semb H (2019) p120ctn-mediated organ patterning precedes and determines pancreatic progenitor fate. Dev Cell 49 (31-47):e39

Oakie A, Li J, Fellows GF, Hess DA, Wang R (2018) Characterization and differentiation of sorted human fetal pancreatic ALDH(hi) and $\mathrm{ALDH}(\mathrm{hi}) / \mathrm{CD} 133(+)$ cells toward insulin-expressing cells. Stem Cells Dev 27:275-286

Ojaghi M, Soleimanifar F, Kazemi A, Ghollasi M, Soleimani M, Nasoohi N, Enderami SE (2019) Electrospun poly-l-lactic acid/ polyvinyl alcohol nanofibers improved insulin-producing cell differentiation potential of human adipose-derived mesenchymal stem cells. J Cell Biochem 120:9917-9926

Okita K, Ichisaka T, Yamanaka S (2007) Generation of germlinecompetent induced pluripotent stem cells. Nature 448:313-317

Oliver-Krasinski JM, Stoffers DA (2008) On the origin of the beta cell. Genes Dev 22:1998-2021

Op de Beeck A, Eizirik DL (2016) Viral infections in type 1 diabetes mellitus-why the beta cells? Nat Rev Endocrinol 12:263-273

O'Sullivan ES, Vegas A, Anderson DG, Weir GC (2011) Islets transplanted in immunoisolation devices: a review of the progress and the challenges that remain. Endocr Rev 32:827-844
Pagliuca FW, Millman JR, Gürtler M, Segel M, Van Dervort A, Ryu JH, Peterson QP, Greiner D, Melton DA (2014) Generation of functional human pancreatic $\beta$ cells in vitro. Cell 159:428-439

Pathak S, Pham TT, Jeong JH, Byun Y (2019) Immunoisolation of pancreatic islets via thin-layer surface modification. J Control Release 305:176-193

Pepper AR, Gala-Lopez B, Pawlick R, Merani S, Kin T, Shapiro AM (2015) A prevascularized subcutaneous device-less site for islet and cellular transplantation. Nat Biotechnol 33:518-523

Petersen MBK, Goncalves CAC, Kim YH, Grapin-Botton A (2018) Recapitulating and deciphering human pancreas development from human pluripotent stem cells in a dish. Curr Top Dev Biol 129:143-190

Phelps EA, Headen DM, Taylor WR, Thule PM, Garcia AJ (2013) Vasculogenic bio-synthetic hydrogel for enhancement of pancreatic islet engraftment and function in type 1 diabetes. Biomaterials 34:4602-4611

Pictet RL, Clark WR, Williams RH, Rutter WJ (1972) An ultrastructural analysis of the developing embryonic pancreas. Dev Biol 29:436-467

Qadir MMF, Alvarez-Cubela S, Klein D, Lanzoni G, Garcia-Santana C, Montalvo A, Placeres-Uray F, Mazza EMC, Ricordi C, Inverardi LA et al (2018) P2RY1/ALK3-expressing cells within the adult human exocrine pancreas are BMP-7 expandable and exhibit progenitor-like characteristics. Cell Rep 22:2408-2420

Qadir MMF, Alvarez-Cubela S, Klein D, van Dijk J, Muniz-Anquela R, Moreno-Hernandez YB, Lanzoni G, Sadiq S, Navarro-Rubio B, Garcia MT et al (2020) Single-cell resolution analysis of the human pancreatic ductal progenitor cell niche. Proc Natl Acad Sci USA 117:10876-10887

Ranjan AK, Joglekar MV, Hardikar AA (2009) Endothelial cells in pancreatic islet development and function. Islets 1:2-9

Rezania A, Bruin JE, Riedel MJ, Mojibian M, Asadi A, Xu J, Gauvin R, Narayan K, Karanu F, O'Neil JJ et al (2012) Maturation of human embryonic stem cell-derived pancreatic progenitors into functional islets capable of treating pre-existing diabetes in mice. Diabetes 61:2016-2029

Rezania A, Bruin JE, Xu J, Narayan K, Fox JK, O’Neil JJ, Kieffer TJ (2013) Enrichment of human embryonic stem cell-derived NKX6.1expressing pancreatic progenitor cells accelerates the maturation of insulin-secreting cells in vivo. Stem Cells 31:2432-2442

Rezania A, Bruin JE, Arora P, Rubin A, Batushansky I, Asadi A, O'Dwyer S, Quiskamp N, Mojibian M, Albrecht T et al (2014) Reversal of diabetes with insulin-producing cells derived in vitro from human pluripotent stem cells. Nat Biotechnol 32:1121-1133

Rodriguez-Seguel E, Mah N, Naumann H, Pongrac IM, CerdaEsteban N, Fontaine JF, Wang Y, Chen W, Andrade-Navarro MA, Spagnoli FM (2013) Mutually exclusive signaling signatures define the hepatic and pancreatic progenitor cell lineage divergence. Genes Dev 27:1932-1946

Rohayem J, Ehlers C, Wiedemann B, Holl R, Oexle K, Kordonouri O, Salzano G, Meissner T, Burger W, Schober E et al (2011) Diabetes and neurodegeneration in Wolfram syndrome: a multicenter study of phenotype and genotype. Diabetes Care 34:1503-1510

Romer Al, Singer RA, Sui L, Egli D, Sussel L (2019) Murine perinatal beta-cell proliferation and the differentiation of human stem cell- 
derived insulin-expressing cells require NEUROD1. Diabetes 68:2259-2271

Rosado-Olivieri EA, Anderson K, Kenty JH, Melton DA (2019) YAP inhibition enhances the differentiation of functional stem cellderived insulin-producing beta cells. Nat Commun 10:1464

Rosado-Olivieri EA, Aigha II, Kenty JH, Melton DA (2020) Identification of a LIF-responsive, replication-competent subpopulation of human beta cells. Cell Metab 31(327-338):e326

Roscioni SS, Migliorini A, Gegg M, Lickert H (2016) Impact of islet architecture on beta-cell heterogeneity, plasticity and function. Nat Rev Endocrinol 12:695-709

Rossen NS, Anandakumaran PN, Zur Nieden R, Lo K, Luo W, Park C, Huyan C, Fu Q, Song Z, Singh-Moon RP et al (2020) Injectable therapeutic organoids using sacrificial hydrogels. iScience 23:101052

Rukstalis JM, Habener JF (2007) Snail2, a mediator of epithelialmesenchymal transitions, expressed in progenitor cells of the developing endocrine pancreas. Gene Expr Patterns 7:471-479

Russ HA, Parent AV, Ringler JJ, Hennings TG, Nair GG, Shveygert M, Guo T, Puri S, Haataja L, Cirulli V et al (2015) Controlled induction of human pancreatic progenitors produces functional beta-like cells in vitro. EMBO J 34:1759-1772

Russell R, Carnese PP, Hennings TG, Walker EM, Russ HA, Liu JS, Giacometti S, Stein R, Hebrok M (2020) Loss of the transcription factor MAFB limits beta-cell derivation from human PSCs. Nat Commun 11:2742

Saarimaki-Vire J, Balboa D, Russell MA, Saarikettu J, Kinnunen M, Keskitalo S, Malhi A, Valensisi C, Andrus C, Eurola S et al (2017) An activating STAT3 mutation causes neonatal diabetes through premature induction of pancreatic differentiation. Cell Rep 19:281-294

Saeedi P, Petersohn I, Salpea P, Malanda B, Karuranga S, Unwin N, Colagiuri S, Guariguata L, Motala AA, Ogurtsova K et al (2019) Global and regional diabetes prevalence estimates for 2019 and projections for 2030 and 2045: results from the International Diabetes Federation Diabetes Atlas, 9(th) edition. Diabetes Res Clin Pract 157:107843

Schutgens F, Clevers H (2020) Human organoids: tools for understanding biology and treating diseases. Annu Rev Pathol 15:211234

Shang L, Hua H, Foo K, Martinez H, Watanabe K, Zimmer M, Kahler DJ, Freeby M, Chung W, LeDuc C et al (2014) beta-cell dysfunction due to increased ER stress in a stem cell model of Wolfram syndrome. Diabetes 63:923-933

Sharon N, Vanderhooft J, Straubhaar J, Mueller J, Chawla R, Zhou Q, Engquist EN, Trapnell C, Gifford DK, Melton DA (2019) Wnt signaling separates the progenitor and endocrine compartments during pancreas development. Cell Rep 27(2281-2291):e2285

Shi ZD, Lee K, Yang D, Amin S, Verma N, Li QV, Zhu Z, Soh CL, Kumar R, Evans T et al (2017) Genome editing in hPSCs reveals GATA6 haploinsufficiency and a genetic interaction with GATA4 in human pancreatic development. Cell Stem Cell 20(675-688): e676

Shih HP, Wang A, Sander M (2013) Pancreas organogenesis: from lineage determination to morphogenesis. Annu Rev Cell Dev Biol 29:81-105
Sneddon JB, Tang Q, Stock P, Bluestone JA, Roy S, Desai T, Hebrok M (2018) Stem cell therapies for treating diabetes: progress and remaining challenges. Cell Stem Cell 22:810-823

Suckale J, Solimena M (2010) The insulin secretory granule as a signaling hub. Trends Endocrinol Metab 21:599-609

Suzuki T, Itoh Y, Sakai Y, Saito A, Okuzaki D, Motooka D, Minami S, Kobayashi T, Yamamoto T, Okamoto T et al (2020) Generation of human bronchial organoids for SARS-CoV-2 research. bioRxiv

Takahashi Y, Sekine K, Kin T, Takebe T, Taniguchi H (2018a) Selfcondensation culture enables vascularization of tissue fragments for efficient therapeutic transplantation. Cell Rep 23:1620-1629

Takahashi Y, Takebe T, Taniguchi H (2018b) Methods for generating vascularized islet-like organoids via self-condensation. Curr Protoc Stem Cell Biol 45:e49

Tao T, Wang Y, Chen W, Li Z, Su W, Guo Y, Deng P, Qin J (2019) Engineering human islet organoids from iPSCs using an organon-chip platform. Lab Chip 19:948-958

Thorel F, Nepote V, Avril I, Kohno K, Desgraz R, Chera S, Herrera PL (2010) Conversion of adult pancreatic alpha-cells to beta-cells after extreme beta-cell loss. Nature 464:1149-1154

Toyoda T, Mae S, Tanaka H, Kondo Y, Funato M, Hosokawa Y, Sudo T, Kawaguchi Y, Osafune K (2015) Cell aggregation optimizes the differentiation of human ESCs and iPSCs into pancreatic bud-like progenitor cells. Stem Cell Res 14:185-197

Van de Casteele M, Leuckx G, Baeyens L, Cai Y, Yuchi Y, Coppens V, De Groef S, Eriksson M, Svensson C, Ahlgren U et al (2013) Neurogenin $3+$ cells contribute to beta-cell neogenesis and proliferation in injured adult mouse pancreas. Cell Death Dis 4: e523

Velazco-Cruz L, Song J, Maxwell KG, Goedegebuure MM, Augsornworawat P, Hogrebe NJ, Millman JR (2019) Acquisition of dynamic function in human stem cell-derived beta cells. Stem Cell Rep 12:351-365

Velazco-Cruz L, Goedegebuure MM, Maxwell KG, Augsornworawat P, Hogrebe NJ, Millman JR (2020) SIX2 regulates human beta cell differentiation from stem cells and functional maturation in vitro. Cell Rep 31:107687

Veres A, Faust AL, Bushnell HL, Engquist EN, Kenty JH, Harb G, Poh YC, Sintov E, Gurtler M, Pagliuca FW et al (2019) Charting cellular identity during human in vitro beta-cell differentiation. Nature 569:368-373

Vethe H, Bjorlykke Y, Ghila LM, Paulo JA, Scholz H, Gygi SP, Chera $\mathrm{S}$, Raeder H (2017) Probing the missing mature beta-cell proteomic landscape in differentiating patient iPSC-derived cells. Sci Rep 7:4780

Viacyte (2014) A safety, tolerability, and efficacy study of VC-01 ${ }^{\mathrm{TM}}$ combination product in subjects with type I diabetes mellitus

Viacyte (2016) One-year follow-up safety study in subjects previously implanted with VC-01 ${ }^{\mathrm{TM}}$

Viacyte (2017a) A safety and tolerability study of VC-02 ${ }^{\mathrm{TM}}$ combination product in subjects with type 1 diabetes mellitus

Viacyte (2017b) A safety, tolerability, and efficacy study of VC-02 ${ }^{\mathrm{TM}}$ combination product in subjects with type 1 diabetes mellitus and hypoglycemia unawareness

Viacyte (2019) A study to evaluate safety, engraftment, and efficacy of VC-01 in subjects with T1 diabetes mellitus 
Wan J, Huang Y, Zhou P, Guo Y, Wu C, Zhu S, Wang Y, Wang L, Lu $Y$, Wang Z (2017) Culture of iPSCs derived pancreatic beta-like cells in vitro using decellularized pancreatic scaffolds: a preliminary trial. Biomed Res Int 2017:4276928

Wang L, Zhan Y, Song E, Yu Y, Jiu Y, Du W, Lu J, Liu P, Xu P, Xu T (2011) HID-1 is a peripheral membrane protein primarily associated with the medial- and trans- Golgi apparatus. Protein Cell 2:74-85

Wang W, Jin S, Ye K (2017) Development of islet organoids from H9 human embryonic stem cells in biomimetic 3D scaffolds. Stem Cells Dev 26:394-404

Wang D, Wang J, Bai L, Pan H, Feng H, Clevers H, Zeng YA (2020) Long-term expansion of pancreatic islet organoids from resident procr(+) progenitors. Cell 180(1198-1211):e1119

Wei P, Li L, Qi H, Zhou HX, Deng CY, Li FR (2012) Reversible immortalization of Nestin-positive precursor cells from pancreas and differentiation into insulin-secreting cells. Biochem Biophys Res Commun 418:330-335

Wei Z, Yoshihara E, He N, Hah N, Fan W, Pinto AFM, Huddy T, Wang Y, Ross B, Estepa G et al (2018) Vitamin D switches BAF complexes to protect beta cells. Cell 173(1135-1149):e1115

Weng C, Xi J, Li H, Cui J, Gu A, Lai S, Leskov K, Ke L, Jin F, Li Y (2020) Single-cell lineage analysis reveals extensive multimodal transcriptional control during directed beta-cell differentiation. Nat Metab 2:1443-1458

Wesolowska-Andersen A, Jensen RR, Alcántara MP, Beer NL, Duff C, Nylander V, Gosden M, Witty L, Bowden R, McCarthy Ml et al (2020) Analysis of differentiation protocols defines a common pancreatic progenitor molecular signature and guides refinement of endocrine differentiation. Stem Cell Rep 14:138-153

Wu Y, Chang T, Long Y, Huang H, Kandeel F, Yee JK (2019) Using gene editing to establish a safeguard system for pluripotent stemcell-based therapies. iScience 22:409-422

Yabe SG, Iwasaki N, Yasuda K, Hamazaki TS, Konno M, Fukuda S, Takeda F, Kasuga M, Okochi H (2015) Establishment of maturityonset diabetes of the young-induced pluripotent stem cells from a Japanese patient. J Diabetes Investig 6:543-547

Yang L, Han Y, Nilsson-Payant BE, Gupta V, Wang P, Duan X, Tang $X$, Zhu J, Zhao Z, Jaffre $F$ et al (2020) A human pluripotent stem cell-based platform to study SARS-CoV-2 tropism and model virus infection in human cells and organoids. Cell Stem Cell 27 (125-136):e127

Yoshihara E, Wei Z, Lin CS, Fang S, Ahmadian M, Kida Y, Tseng T, Dai Y, Yu RT, Liddle C et al (2016) ERRgamma is required for the metabolic maturation of therapeutically functional glucose-responsive beta cells. Cell Metab 23:622-634

Yoshihara E, O'Connor C, Gasser E, Wei Z, Oh TG, Tseng TW, Wang D, Cayabyab F, Dai Y, Yu RT et al (2020) Immune-evasive human islet-like organoids ameliorate diabetes. Nature 586:606611

Youn DY, Xiaoli AM, Pessin JE, Yang F (2016) Regulation of metabolism by the Mediator complex. Biophys Rep 2:69-77

Youngblood RL, Sampson JP, Lebioda KR, Shea LD (2019) Microporous scaffolds support assembly and differentiation of pancreatic progenitors into beta-cell clusters. Acta Biomater 96:111-122

Yu XX, Xu CR (2020) Understanding generation and regeneration of pancreatic beta cells from a single-cell perspective. Development 147

Zeng $\mathrm{H}$, Guo M, Zhou T, Tan L, Chong CN, Zhang T, Dong X, Xiang JZ, Yu AS, Yue L et al (2016) An isogenic human ESC platform for functional evaluation of genome-wide-association-study-identified diabetes genes and drug discovery. Cell Stem Cell 19:326340

Zhang X, McGrath PS, Salomone J, Rahal M, McCauley HA, Schweitzer J, Kovall R, Gebelein B, Wells JM (2019) A comprehensive structure-function study of neurogenin3 disease-causing alleles during human pancreas and intestinal organoid development. Dev Cell 50(367-380):e367

Zhou T, Kim TW, Chong CN, Tan L, Amin S, Sadat Badieyan Z, Mukherjee S, Ghazizadeh Z, Zeng H, Guo M et al (2018) A hPSC-based platform to discover gene-environment interactions that impact human beta-cell and dopamine neuron survival. Nat Commun 9:4815

Zhou X, Nair GG, Russ HA, Belair CD, Li ML, Shveygert M, Hebrok M, Blelloch R (2020) LIN28B impairs the transition of hESCderived beta cells from the juvenile to adult state. Stem Cell Rep 14:9-20

Zhu P, Fan Z (2018) Cancer stem cells and tumorigenesis. Biophys Rep 4:178-188

Zhu Z, Li QV, Lee K, Rosen BP, Gonzalez F, Soh CL, Huangfu D (2016) Genome editing of lineage determinants in human pluripotent stem cells reveals mechanisms of pancreatic development and diabetes. Cell Stem Cell 18:755-768

Zhu L, She ZG, Cheng X, Qin JJ, Zhang XJ, Cai J, Lei F, Wang H, Xie J, Wang W et al (2020) Association of blood glucose control and outcomes in patients with COVID-19 and pre-existing type 2 diabetes. Cell Metab 31(1068-1077):e1063 